\title{
Implementing a Zero Energy Ready Home Multifamily Project
}

David Springer and Alea German Alliance for Residential Building Innovation 


\section{NOTICE}

This report was prepared as an account of work sponsored by an agency of the United States government. Neither the United States government nor any agency thereof, nor any of their employees, subcontractors, or affiliated partners makes any warranty, express or implied, or assumes any legal liability or responsibility for the accuracy, completeness, or usefulness of any information, apparatus, product, or process disclosed, or represents that its use would not infringe privately owned rights. Reference herein to any specific commercial product, process, or service by trade name, trademark, manufacturer, or otherwise does not necessarily constitute or imply its endorsement, recommendation, or favoring by the United States government or any agency thereof. The views and opinions of authors expressed herein do not necessarily state or reflect those of the United States government or any agency thereof.

Available electronically at http://www.osti.gov/scitech

Available for a processing fee to U.S. Department of Energy and its contractors, in paper, from:

U.S. Department of Energy

Office of Scientific and Technical Information

P.O. Box 62

Oak Ridge, TN 37831-0062

phone: 865.576 .8401

fax: 865.576 .5728

email: mailto:reports@adonis.osti.gov

Available for sale to the public, in paper, from:

U.S. Department of Commerce

National Technical Information Service

5285 Port Royal Road

Springfield, VA 22161

phone: 800.553 .6847

fax: 703.605.6900

email: orders@ntis.fedworld.gov

online ordering: http://www.ntis.gov/ordering.htm 


\title{
Implementing a Zero Energy Ready Home Multifamily Project
}

\author{
Prepared for: \\ The National Renewable Energy Laboratory \\ On behalf of the U.S. Department of Energy's Building America Program \\ Office of Energy Efficiency and Renewable Energy \\ 15013 Denver West Parkway \\ Golden, CO 80401 \\ NREL Contract No. DE-AC36-08GO28308 \\ Prepared by: \\ David Springer and Alea German \\ Alliance for Residential Building Innovation \\ 123 C Street \\ Davis, CA 95616 \\ NREL Technical Monitor: Stacey Rothgeb \\ Prepared under Subcontract No.: KNDJ-0-40340-05
}

Revised August 2015 
The work presented in this report does not represent performance of any product relative to regulated minimum efficiency requirements.

The laboratory and/or field sites used for this work are not certified rating test facilities. The conditions and methods under which ZERH products were characterized for this work differ from standard rating conditions, as described.

Because the methods and conditions differ, the reported results are not comparable to rated product performance and should only be used to estimate performance under the measured conditions. 


\section{Contents}

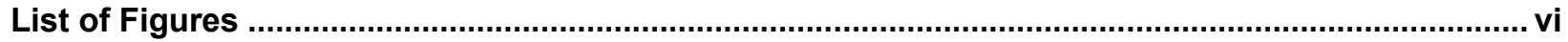

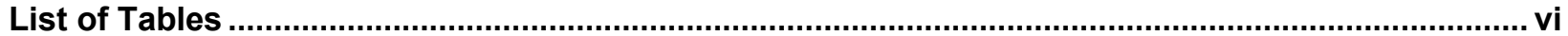

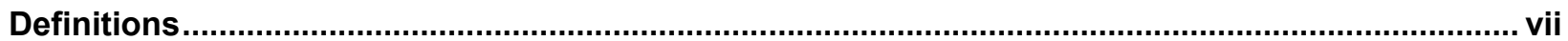

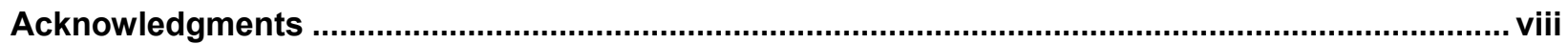

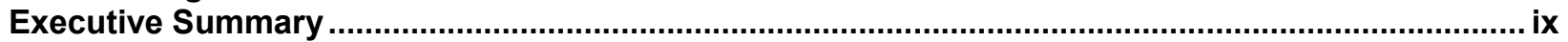

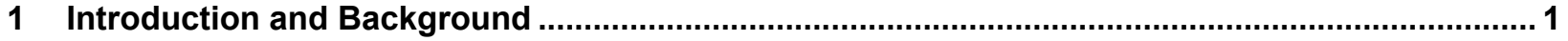

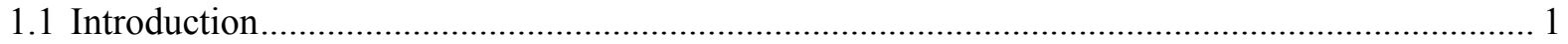

1.2 The Zero Energy Ready Home Program in California ............................................................ 2

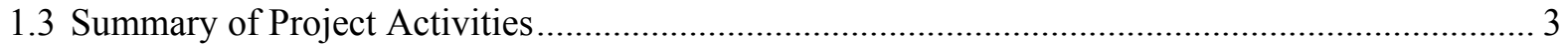

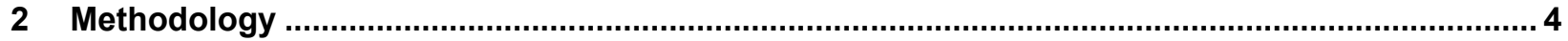

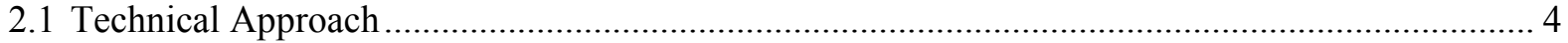

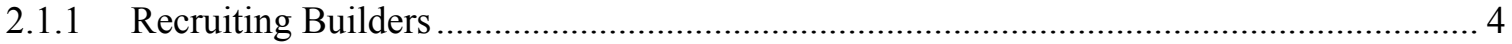

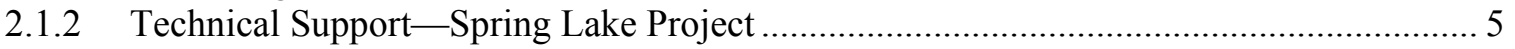

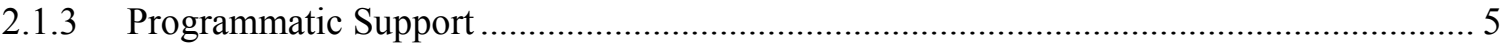

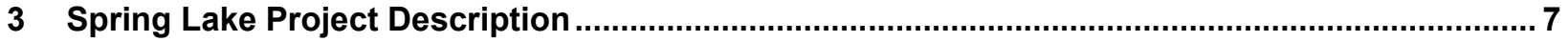

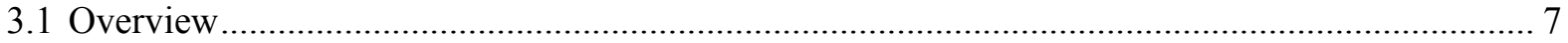

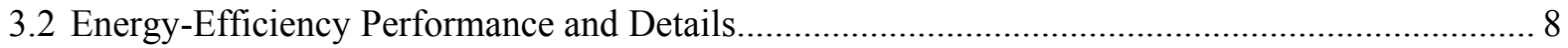

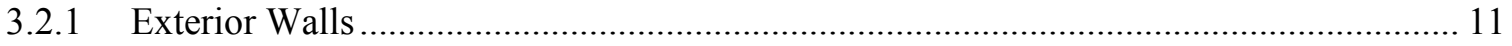

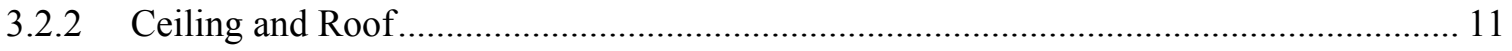

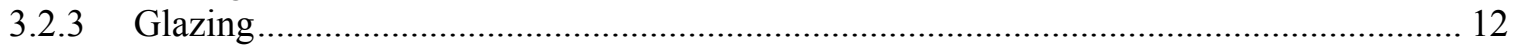

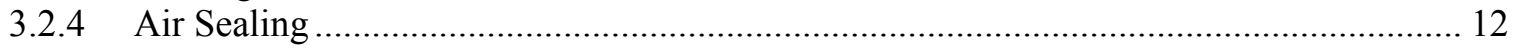

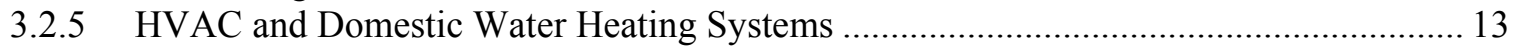

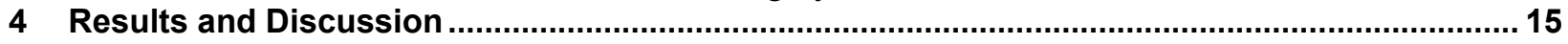

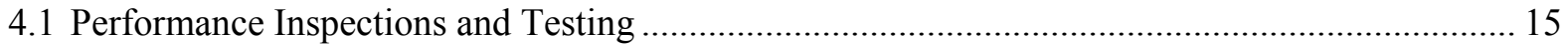

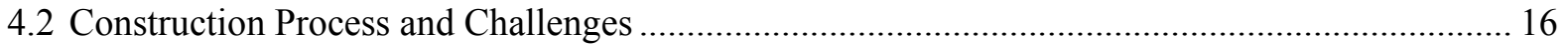

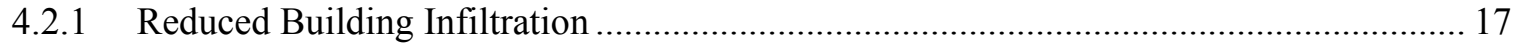

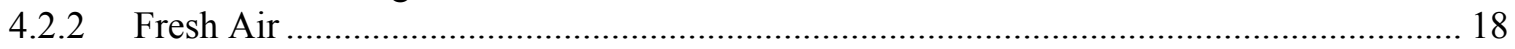

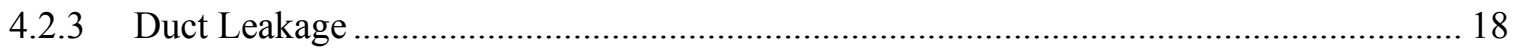

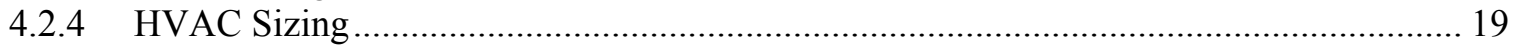

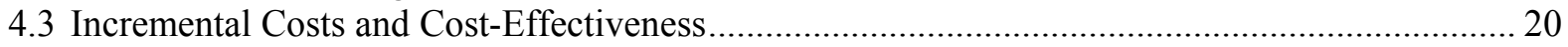

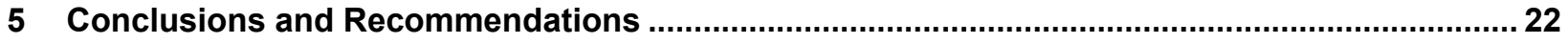

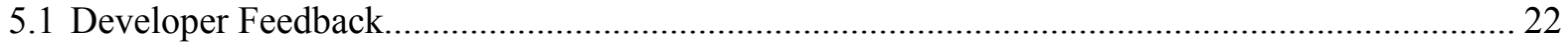

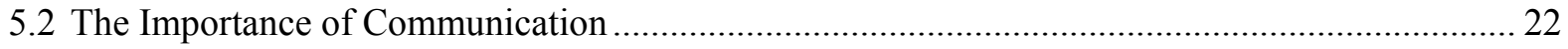

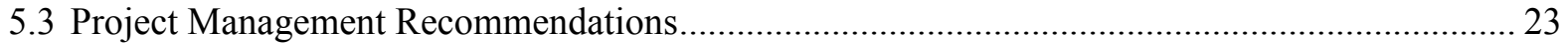

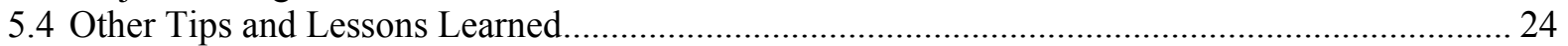

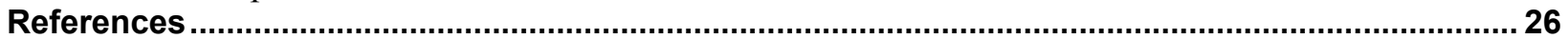

Section 4.3 and Table 5 were revised from an earlier version. 


\section{List of Figures}

Figure 1. Artistic rendering of Mutual Housing's Spring Lake community ..................................... 8

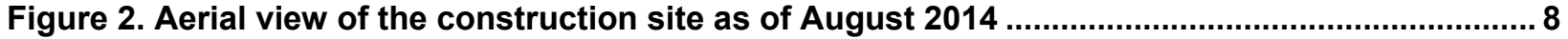
Figure 3. Attaching intersecting walls using a flat $2 \times 6$ stud instead of ladder blocking provides a

nailing surface for drywall. ................................................................................................. 11

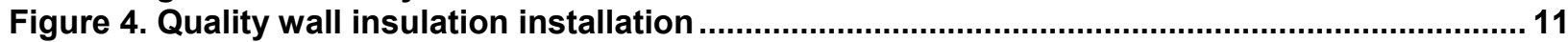

Figure 5: Raised heel trusses in townhomes (left); rigid insulation in apartment building (right) .. 12

Figure 6. Altherma outdoor unit (left); water heater closet with storage tank and hydrobox (right) 13

Figure 7. Supply plenum in mechanical closet (left); ducts in furred hallway ceiling (right) ........... 14

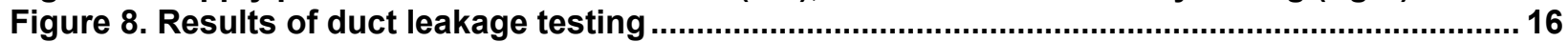

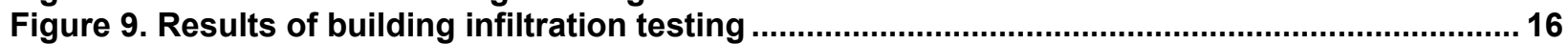

Figure 10. Methods used to seal electrical boxes at exterior walls (left); interior walls (right) ........ 17

Figure 11. Leakage through subfloor (left); stairs in townhouse unit evident during depressurization (right)

Unless otherwise noted, all figures were created by the Alliance for Residential Building Innovation.

\section{List of Tables}

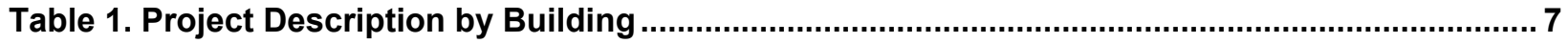

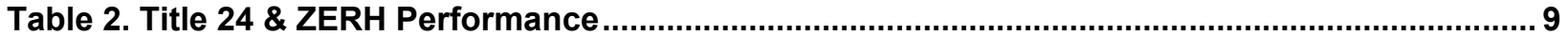

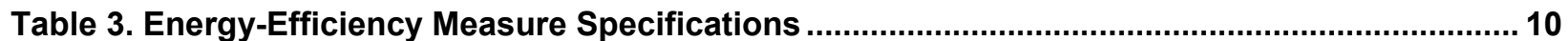

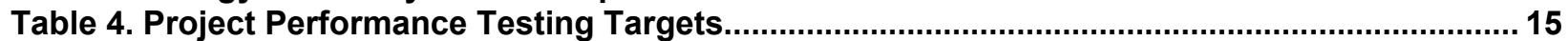

Table 5. Incremental Costs of ZERH and LEED Measures .......................................................... 21

Unless otherwise noted, all tables were created by the Alliance for Residential Building Innovation. 


\section{Definitions}

ACCA

ACH50

ARBI

ASHRAE

CAHP

CFA

CRRC

DEG

DOE

HERS

HVAC

LED

LEED

PG\&E

PV

SHGC

ZERH
Air-Conditioning Contractors of America

Air changes per hour@50 Pascals

Alliance for Residential Building Innovation

American Society of Heating, Refrigerating and Air-

Conditioning Engineers

California Advanced Homes Program

Conditioned Floor Area

Cool Roof Rating Council

Davis Energy Group

U.S. Department of Energy

Home Energy Rating System

Heating, Ventilating, and Air Conditioning

Light-Emitting Diode

Leadership in Energy \& Environmental Design

Pacific Gas \& Electric Company

Photovoltaics

Solar Heat Gain Coefficient

Zero Energy Ready Home 


\section{Acknowledgments}

The Alliance for Residential Building Innovation team acknowledges the strong commitment of all project participants to work through all of the obstacles encountered on the way to Zero Net Energy Home certification. Mutual Housing, the developer, seemed undaunted by each obstacle that was presented. Sunseri Construction, the general contractor, accepted each new twist as a challenge and contributed solutions that can be applied to future projects. The subcontractors likewise applied their best skills to ensure the project would meet the design intent.

Newport Partners, which provides support for the U.S. Department of Energy's Zero Energy Home Program, also deserves high praise for its rapid response to questions and guidance and flexibility with interpreting ENERGY STAR ${ }^{\circledR}$ and Zero Energy Ready Home program requirements. 


\section{Executive Summary}

Building cost-effective, high-performance homes that provide superior comfort, health, and durability is the goal of the U.S. Department of Energy's (DOE's) Zero Energy Ready Home (ZERH) program. Building America research and other innovative programs throughout the country have addressed many of the technical challenges of building to the ZERH standard. The cost-effectiveness of measure packages that result in 30\% source energy savings compared to a code-compliant home have been demonstrated. However, additional challenges remain, particularly with respect to convincing production builders of the strong business case for ZERH. The Alliance for Residential Building Innovation (ARBI) team believes that the keys to successfully engaging builders and developers in the California market are to help them leverage development agreement requirements, code compliance requirements, incentives, and competitive market advantages of ZERH certification, and navigate through this process.

A primary objective of this project was to gain a highly visible foothold for residential buildings that are built to the DOE ZERH specification that can be used to encourage participation by other California builders. This report briefly describes two single-family homes that were ZERH certified and focuses on the experience of working with developer Mutual Housing on a 62-unit multifamily community at the Spring Lake subdivision in Woodland, California. The Spring Lake project is expected to be the first ZERH-certified multifamily project in the country. This report discusses the challenges encountered, lessons learned, and how obstacles were overcome.

This was the developer's first attempt at building to both ZERH and zero energy standards, although it has been building above code and pursuing green building through programs such as Build It Green for the past 7 years. Mutual Housing expressed that the most difficult aspects of this project included fully understanding all the performance specifications and ensuring that all team members were on board and had a clear understanding of what needed to be done. Some of these challenges could have been alleviated if the design team had more carefully reviewed and incorporated the ZERH requirements early in the design process. Having access to information from a previous ZERH-certified multifamily project would have also been useful to the developer had this not been the first of its kind. Mutual Housing's recommendations for future projects are to develop a firm understanding of requirements and coordinate those requirements with the design team, consultants, contractors, installers, and verifiers as early as possible. Even after facing these challenges, Mutual Housing considers this project a success and plans to build more projects to the ZERH standard.

Other important lessons learned include the following items, which are discussed further in this report:

- Communication initiated early in the design process and maintained throughout the project is crucial to the success of high-performance buildings. ARBI recommends that roles and responsibilities be clearly defined and an individual identified to manage and coordinate ZERH-related work.

- Early design meetings and periodic reviews of construction documents should be held to ensure that all measures and testing requirements are addressed; this will help avert change orders and reduce costs. 
- $\quad$ Detailed scopes of work that list unique ENERGY STAR ${ }^{\circledR}$ and ZERH requirements should be provided to the bidding contractors and reviewed again before construction begins. Compliance should be reviewed as construction progresses.

- Air sealing can be a challenge in multifamily buildings. The air barrier should be explicitly defined in the construction documents. Particular care should be taken in sealing rim joists and sealing drywall to top plates; these require coordination between the drywall contractor and insulator.

- Proper design, installation, and sealing of ductwork are important even when ducts are located fully within conditioned living space. Duct and equipment sealing, methods for avoiding pressure imbalances, and air-balancing requirements must be clearly addressed in the design and managed during construction.

- Use of low-leakage air handlers and providing adequate access in mechanical closets to seal equipment to plenums will reduce the need for mitigating leakage when systems do not pass testing.

The close coordination that ZERH program managers provided for this project was extremely helpful; they interpreted the California-specific ENERGY STAR and ZERH requirements and helped to overcome several obstacles. For example, the program managers (DOE and Newport Partners) agreed to increase the blower door test leakage for all multifamily buildings from 3.0 to 4.0 ACH50, and the ZERH duct leakage requirement was clarified to be "leakage to outside" instead of total leakage. DOE and the U.S. Environmental Protection Agency would benefit from considering future amendments to ZERH program requirements, including allowances for different sizing criteria for the increasingly common variable-speed heat pumps such as those that were used in the Spring Lake project. 


\section{Introduction and Background}

\subsection{Introduction}

Building cost-effective, high-performance homes that provide superior comfort, health, and durability is the goal of the U.S. Department of Energy's (DOE's) Zero Energy Ready Home (ZERH) program. Building America research and other innovative programs throughout the country have addressed many of the technical challenges of building to the ZERH standard. The cost-effectiveness of measure packages that result in 30\% source energy savings compared to a code-compliant home has been demonstrated. California's goal to achieve zero energy for new residential buildings by 2020 is narrowing the gap between the ZERH level of performance and the state's energy code (Title 24).

However, additional challenges remain, particularly with respect to convincing production builders of the strong business case for ZERH. Although 14,000 homes have been certified under the former DOE Builders Challenge program nationally, few California builders participated. Of the approximate 75,000 single-family homes built in California during 2013 and 2014, only three were certified ZERH. Reasons given for their lack of interest in ZERH by builders approached by the Alliance for Residential Building Innovation (ARBI) team include:

- The slow housing market recovery and "buyer's market" is making them more costconscious.

- Most of the low-cost distressed properties have been acquired by builders, and higher land prices are putting downward pressure on construction costs.

- The recent rapid increase in construction activity is straining builder resources.

- The rigorous requirements of ENERGY STAR ${ }^{\circledR}$ Version 3 have caused most builders who participated in Version 2 to abandon that program.

- With tighter California Title 24 energy standards, profits are too slim to build above code, and they feel their homes are efficient enough.

- Resources are lacking for navigating through ZERH requirements and understanding how they relate to Title 24, the CalGreen code, and the California Advanced Home (CAHP) incentive program and understanding the net costs and benefits.

- They already have successful proprietary brands (for example, "SheaXero") and don't need ZERH.

- No data are available that indicate whether and how much ZERH certification California buyers value.

Market successes experienced by some builders with ENERGY STAR and green programs such as Leadership in Energy \& Environmental Design (LEED) for Homes show that national certifications can play a role and that adoption can be significant provided programs are consistent over the long term and have a clear path to implement them. According to DOE, Pulte Homes builds the most ENERGY STAR-certified homes nationwide, and its Las Vegas division has built 100\% ENERGY STAR homes since 1999 (DOE 2009). Evidence is also increasing that buyers value energy efficiency and renewable energy. Homes certified by Earth Advantage in the 
Seattle metro area sold at a price premium of $9.6 \%$ compared to noncertified counterparts, and certified homes stayed on the market for 18 fewer days than noncertified homes (Griffin et al. 2009). A Lawrence Berkeley National Laboratory study found that an average $\$ 17,000$ premium for new homes equipped with photovoltaic (PV) systems did not discourage sales (LBNL 2011). The experience of Davis Energy Group (DEG)/Consortium for Advanced Residential Buildings with Grupe Homes in 2006-2007 demonstrated the competitive advantage and marketing value of energy efficiency and how the increased construction costs can be more than offset by savings that result from accelerated turnover rates that are attributable to reduced holding costs (Dakin et al. 2008).

The ARBI team believes that the keys to successfully recruiting builders and developers in the California market are to show them how to leverage entitlements, development agreement requirements, code compliance requirements, incentives, and competitive market advantages of ZERH certification, and help them navigate through this process. Having at least one ZERHcertified model in a community can enable builders to test the waters and will help drive customer demand.

A primary objective of this project was to gain a highly visible foothold for residential buildings built to the DOE ZERH specification that can be used to encourage participation by other California builders. This report focuses on results from working with developer Mutual Housing on a 62-unit multifamily community at the Spring Lake subdivision in Woodland, California. Ground-breaking efforts with builder-developer The New Homes Company, which is building single-family units in its Cannery Park community in Davis, California, are also reviewed. This report discusses the challenges encountered, lessons learned, and how roadblocks were overcome. The primary research questions addressed by this project were: What challenges are unique to multifamily buildings in meeting the ZERH specification in California, and how can they best be addressed?

Additional research questions that were evaluated include:

- In California climates, what are the most cost-effective energy-efficiency packages that achieve the ZERH specification?

- How can ZERH be integrated with above-code programs such as California Title 24 "reach codes" and leveraged with other state requirements such as CalGreen and national programs such as LEED?

Questions related to the marketability of ZERH-certified homes cannot be answered by this project because of timing.

\subsection{The Zero Energy Ready Home Program in California}

DOE developed California-specific ZERH program guidelines that went into effect in conjunction with the new Title 24 energy code on July 1, 2014 (DOE 2014). This was an important milestone, because without it, projects seeking ZERH certification would have to show compliance using national software not typically employed on California projects. The need to use unfamiliar software such as REM/Rate in addition to compliance software added costs that builders were not interested in supporting just so they could determine possible eligibility. The 
California-specific guidelines that apply a minimum performance requirement of $25 \%$ better than the 2013 Title 24 code $^{1}$ and mandatory requirements similar to those specified under the national guidelines facilitated the ability of consultants to identify the opportunity for participation early in the process and consequently improved chances for builder participation.

DEG/ARBI introduced the ZERH program to Pacific Gas \& Electric (PG\&E) program managers early in 2013. As a result, the recently updated statewide utility incentive program, the California Advanced Home Program, or CAHP, awards three incentive points to certified ZERH projects, providing up to $\$ 600$ in additional incentives for a single-family home. The updated CAHP, which became effective July 1, 2014, should help spur widespread builder awareness of, and interest in, ZERHs.

The ARBI team also aided DOE's ZERH initiative by encouraging builder participation in webinars, distributing invitations to the Housing Innovation Awards presentations, and holding one-on-one meetings. Efforts were also made to convince PG\&E Zero Net Energy program managers to use ZERH to leverage their program, but they preferred to keep their programs separate and distinct.

\subsection{Summary of Project Activities}

ARBI initially worked with several builders in the Fresno area that were building above code and, with support from PG\&E, were constructing test houses with ducts in conditioned space and high-performance walls. The tightening economic conditions made these builders unwilling to move forward with ZERH certification.

Through a relationship with Mutual Housing, a developer of affordable multifamily homes to provide LEED certification, ${ }^{2}$ DEG/ARBI learned that there was interest in also pursuing ZERH certification. Some of the groundwork had been laid, including the inclusion of ducts in conditioned space in the design. Most of the information provided in this report centers around this project, Spring Lake by Mutual Housing, located in Woodland, California. This project is on track to be the first ZERH-certified multifamily project in the United States.

ARBI also participated in efforts to certify two individual homes, including a home designed to Passive House standards located in San Jose (PNNL 2014). This project, referred to as the Cottle Zero Energy House, was the subject of a previous Building America project. ARBI helped the builder select heating, ventilating, and air-conditioning (HVAC) and water heating systems during the early stages of design. One Sky is only the second California builder to receive ZERH certification. Detailed monitoring of the Cottle House was supported under PG\&E's Zero Energy Homes Project (PG\&E 2014).

Another home, the "Honda Smart Home US," is a test house in Davis, California, that was built by Honda Motor Company and was certified through the ZERH program with support from ARBI. Green Builder Media recently named the Honda Smart Home US *Best Demonstration Home of the Year*.

\footnotetext{
${ }^{1}$ Based on time-dependent valuation source energy use for space heating and cooling, ventilation, and domestic hot water.

${ }^{2}$ DEG is a LEED for Homes Provider.
} 


\section{Methodology}

\subsection{Technical Approach}

Project activities included builder recruitment, technical support, programmatic support, verification, and process documentation.

\subsubsection{Recruiting Builders}

ARBI began aggressively recruiting builders and developers to the ZERH program in early 2013, primarily those in the Fresno area that DEG was working with on other projects and that were already building to a level far above code. Initially the response from these builders was very positive. In some cases their current designs already met $75 \%-90 \%$ of the ZERH specification. However, these projects began dropping out. The key concern expressed was that the increasing cost of land, combined with the more stringent 2013 Title 24 requirements, was stressing their margins. These builders already had established reputations for energy-efficient design and apparently felt the additional gains from ZERH certification were difficult to justify. In one case the requirement for sizing cooling systems within $115 \%$ of the Air-Conditioning Contractors of America (ACCA) Manual J design heat gain was a sufficient disincentive; the builder and his HVAC subcontractor had received anecdotal information about legal claims related to inadequate comfort and were not willing to accept the risk of "right" sizing.

Additional efforts were made to convince The New Home Company, the developer of a large community in Davis, California, to build to ZERH specifications. The project is Cannery Park, located on the former Hunt-Wesson cannery site. The developer will build most of the units. This project is a 467 -unit mixed-use community with single- and multifamily housing types. The project groundbreaking is planned for early 2015 . DEG became involved with this project early in the planning stage and had the opportunity to participate in the selection of efficiency and sustainability features. As part of the development agreement with the City of Davis, all homes must be at least $40 \%$ more efficient than the 2008 Title 24 energy code, ${ }^{3}$ and at least the first 25 homes will be provided with sufficient PV capacity to achieve zero electricity. Having the energy features established for the entire project before it goes to bid is expected to yield lower bids than if they were implemented on individual houses or by change orders and will save time. Simulations show that this project can meet the $25 \%$ required energy savings relative to Title 24 , but in the end the developer's concerns about the lack of continuing Building America support, timing, and staff limitations moved it away from ZERH certification.

ARBI successfully identified one major project that committed to ZERH. The Spring Lake project was completed in March 2015, received ZERH certification in April, and is the focus of this report. During the planning stages, Mutual Housing used its commitment to ZERH as an inducement to secure project funding from the U.S. Department of Agriculture. ARBI became aware of Mutual Housing's intent when DEG was selected to provide LEED certification for the project. By that time construction drawings had been completed, and because the design team was not cognizant of all the requirements, change orders were required to meet all the ZERH specifications.

\footnotetext{
${ }^{3}$ During these negotiations the 2008 code was in effect; therefore, the agreement is based on this code and not the 2013 code, although the project will apply for the permit under the 2013 code.
} 


\subsubsection{Technical Support-Spring Lake Project}

Immediately after becoming engaged by Mutual Housing, ARBI obtained a plan set and specifications and completed a review to determine compliance with ENERGY STAR and ZERH requirements and checklists. California's Building Energy Code Compliance software was used to model all unit types and to verify that they met the California-specific performance requirements. A meeting was held in February 2014 with the developer, builder, and mechanical, electrical, and insulation trades to review the responsibilities for each trade.

During construction ARBI worked with the team to identify strategies to address the technical and documentation challenges. For example, the plans did not specify the location of the air barrier. The design did not allow the exterior building wrap to be used as the air barrier, and assistance was provided to identify what would be necessary to create a barrier at the drywall. The builder had no expectation that drywall needed to be sealed to top plates, and methods for accomplishing this were reviewed. Also, conflicts between structural requirements and the need to integrate advanced wall framing features were reviewed and solutions were developed.

The builder wisely selected one townhouse unit and one apartment flat as prototypes so that problems with construction details could be identified and resolved before all the units were completed. ARBI used that opportunity to complete blower door and duct leakage tests so that the builder and HVAC contractor could be made aware of various sealing requirements in advance. Through this process the need to seal electrical boxes and other leaks was identified. Excessive leakage at the connection between the fan coil cabinet and plenums was revealed and corrections were implemented. Blower door tests of the townhouse prototype were repeated three times before leakage points could be identified and plugged to achieve the required $4 \mathrm{ACH} 50 .{ }^{4}$ Building America Solution Center examples were used to provide typical solutions.

ARBI served as a liaison to Newport Partners ${ }^{5}$ and DOE to help clarify requirements. For example, the ZERH specification called for no more than 3 CFM25 per $100 \mathrm{ft}^{2}$ total leakage for the buried ducts that are located in the attic of the townhouses. ARBI clarified that measurement of the leakage rate is leakage to outdoors (including the vented attic), not combined indooroutdoor leakage. The procedure for measuring leakage to outdoors had already been established and is described in detail in the Reference Appendices of the 2013 Title 24 standards $^{6}$ (CEC 2012). This method pressurizes the building to $25 \mathrm{~Pa}$ using a blower door and uses a duct blaster to set the duct pressure to $0 \mathrm{~Pa}$ relative to indoor air. The cubic feet per minute delivered by the duct blaster were used to determine duct leakage to outdoors.

DEG/ARBI staff provided Home Energy Rating System (HERS) verifications for Title 24 measures and checklist requirements. Assistance with completion of checklists and applications for certificates was also provided.

\subsubsection{Programmatic Support}

Early in the project ARBI helped facilitate meetings with PG\&E staff and Travelers Research Corporation Energy Services (TRC), which manages the CAHP to acquaint staff with the ZERH

\footnotetext{
${ }^{4} \mathrm{DOE}$ approved a reduction from the originally required $3 \mathrm{ACH} 50$ for multifamily buildings.

${ }^{5}$ Newport Partners manages the ZERH program for DOE.

${ }^{6}$ Section RA3.1.4.3.4
} 
program. An important outcome of these meetings was that CAHP now assigns 3 HERS points to homes that are ZERH certified, which can result in up to $\$ 600$ in additional incentives. ARBI also facilitated a training session with DOE's Sam Rashkin on ZERH at PG\&E's Stockton Training Center.

Other early support included providing Newport Partners with simulations that use early release versions of 2013 Title 24 compliance models. The objective of this work was to examine the equivalency of the $25 \%$ better-than-Title 24 California performance requirement with national ZERH performance requirements. ARBI also helped to develop the following clarifications and proposed changes to the California ZERH specification ${ }^{7}$ :

- Confirmed that the Americans with Disabilities Act requirement, which limits the scope of paved surface leading to residences to $2 \%$, takes precedence over the Water Management Checklist requirement (Item 1.1) for a slope $>0.25$ inch per foot, or $>2.1 \%$.

- Clarified that the requirement for $\leq 3$ CFM25 per $100 \mathrm{ft}^{2}$ of conditioned floor area (CFA) leakage from buried ducts is leakage to outside only (not total).

- Increased the air change rate for multifamily buildings from $3 \mathrm{ACH} 50$ to $4 \mathrm{ACH} 50$.

- Provided information about California compliance requirements for mini-split heat pumps that led to ZERH program acceptance of performance verifications using AirConditioning, Heating, and Refrigeration Institute ratings (California applies minimum DOE performance ratings and the assumption that ductless mini-split systems have ducts located in the attic).

- Coordinated with DOE on the use of high-performance attics as an alternate compliance path to ducts in conditioned space.

- Explored the option of allowing two-speed or variable-speed air conditioners or heat pumps to overcome the problem of builder exposure to liability that results from comfort complaints when systems are sized in accordance with ACCA Manual J.

\footnotetext{
${ }^{7}$ In an effort to align ZERH requirements with California's Title 24 standards, DOE developed specific program requirements for California.
} 


\section{Spring Lake Project Description}

\subsection{Overview}

The Spring Lake development covers 1,097 acres immediately south of Woodland, California. The first building permits were issued in 2005; development is expected to continue until at least 2020. Mutual Housing California is a nonprofit whose mission is to develop, operate, and advocate for sustainable housing in Sacramento and Yolo counties. The Spring Lake project broke ground in December 2013 and includes 62 affordable apartment flats and townhomes. Sixty-one units are being rented to agricultural workers and their families who earn $30 \%-50 \%$ of the area's median income. One apartment is reserved for an on-site manager. In addition to helping the builder navigate ZERH requirements, DEG provided LEED certification ${ }^{8}$ and learned of the builder's interest in ZERH through this contact. The complementary requirements of these programs helped to keep rating and verification costs down. Table 1 describes each of the four building types. An artistic rendering is provided in Figure 1 and an aerial photo is shown in Figure 2.

Table 1. Project Description by Building

\begin{tabular}{c|c|c|c}
\hline Building & \# Bldgs & Type & Description \\
\hline Building A & 1 & 3-story flats & $\begin{array}{c}\text { (20) } 929 \mathrm{ft}^{2} 2 \text {-bedroom and } \\
\text { (6) } 1,287 \mathrm{ft}^{2} \text { 4-bedroom }\end{array}$ \\
Building B & 1 & 3-story flats & $\begin{array}{c}\text { (12) } 709 \mathrm{ft}^{2} 1 \text {-bedroom and } \\
\text { (12) } 1,082 \mathrm{ft}^{2} \text { 3-bedroom }\end{array}$ \\
Building C/E & 2 & 2-story townhouse & $\begin{array}{c}\text { (2) } 1,360 \mathrm{ft}^{2} 3 \text {-bedroom and } \\
\text { (2) } 1,390 \mathrm{ft}^{2} \text { 3-bedroom }\end{array}$ \\
Building D & 1 & 2-story townhouse & $\begin{array}{c}\text { (2) } 1,360 \mathrm{ft}^{2} 3 \text {-bedroom and } \\
\text { (2) } 1,515 \mathrm{ft}^{2} \text { 4-bedroom }\end{array}$ \\
\hline
\end{tabular}

Mutual Housing committed to the ZERH program and designed for zero energy to leverage funding under a grant provided by the U.S. Department of Agriculture. Committing to these high-performance goals provided Mutual Housing an advantage in the grant application process. These goals also aligned with Mutual Housing's mission to incorporate green building practices in its projects to bring the benefits of sustainable and efficient design to low-income residents.

The project was initially designed to incorporate natural gas for space heating and other end uses. However, the project eliminated the use of natural gas to directly offset all energy use on site with electricity generated by PV. Each building will have a virtual net metering account with the utility.

\footnotetext{
${ }^{8}$ The project achieved LEED Platinum.
} 


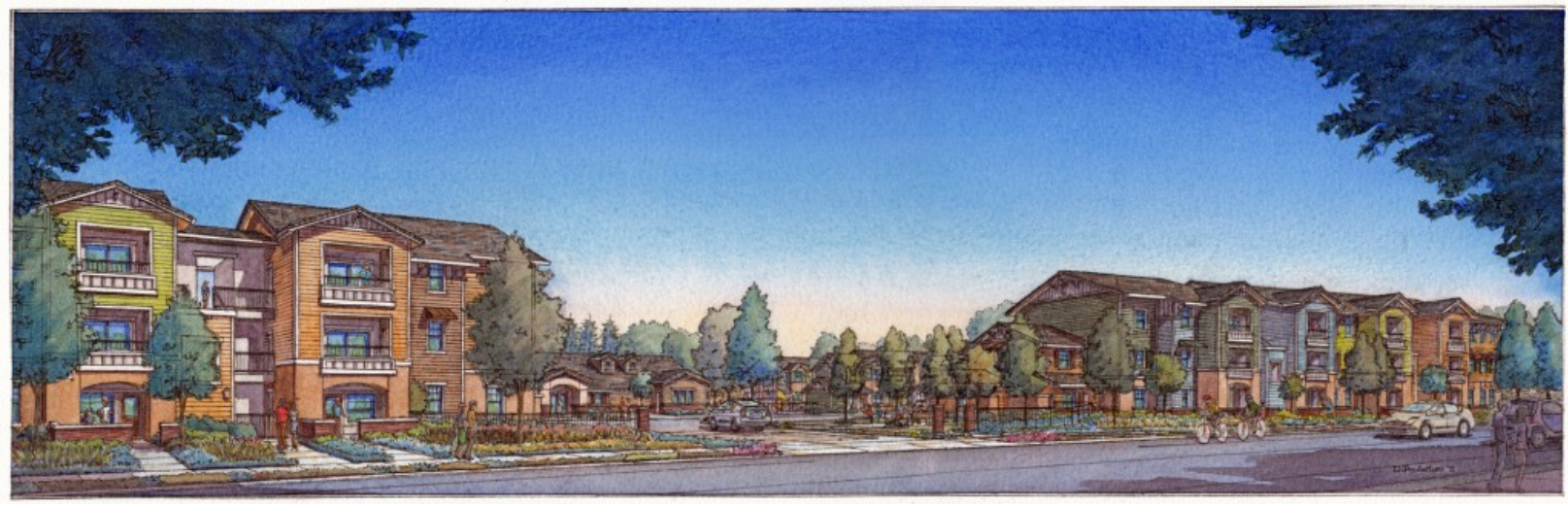

Figure 1. Artistic rendering of Mutual Housing's Spring Lake community

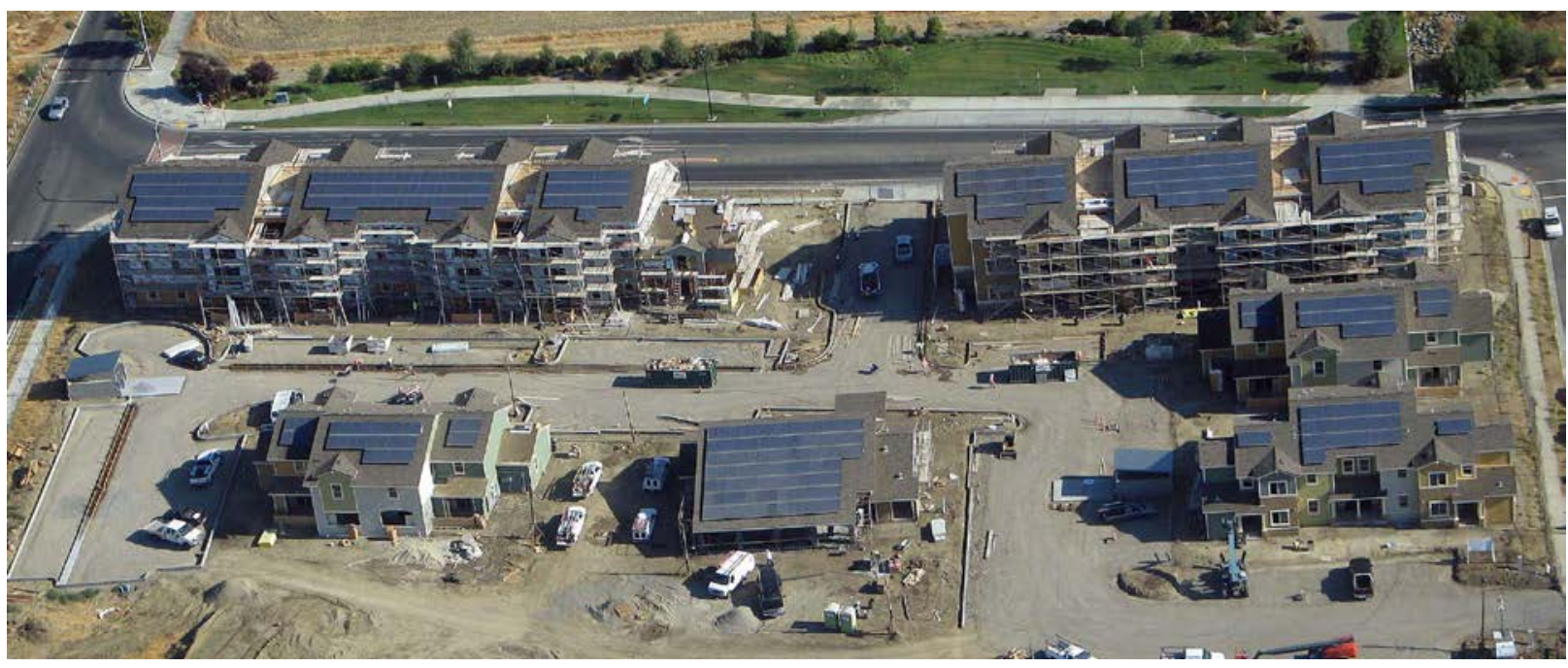

Figure 2. Aerial view of the construction site as of August 2014

\subsection{Energy-Efficiency Performance and Details}

The California ZERH program requirements for California provide one prescriptive path (A) and two prescriptive paths (B and C) to demonstrate compliance. Options B and C use software that was approved by the California Energy Commission for compliance with the 2013 Title 24 energy standards. Option B requires that the rated home achieve a minimum $25 \%$ compliance margin relative to the 2013 Title 24 energy code and would have been the most expedient approach. However, under Title 24 electric water heating (used in this project) is penalized because the time-dependent valuation method used by the standards values peak electricity use much higher than off-peak electricity or natural gas use.

Table 2 demonstrates that none of the buildings met this $25 \%$ threshold; therefore, Option C was used. Option C provides for two models to be created, one that meets ZERH mandatory prescriptive requirements (the "Target Home") and the other that represents the as-built or "rated" design. The rated home must perform better by any margin than the Target Home. Results in Table 2 project that the buildings will perform 13\%-15\% better than the Target Home. 
Table 2. Title 24 \& ZERH Performance ${ }^{9}$

\begin{tabular}{c|c|c|c}
\hline Building & Case & $\begin{array}{c}\mathbf{2 0 1 3} \text { Title 24 } \\
\text { Compliance Margin }\end{array}$ & $\begin{array}{c}\text { \% Better Than } \\
\text { Target }\end{array}$ \\
\hline \multirow{2}{*}{ Building A } & Target ZERH & $5 \%$ & - \\
\multirow{2}{*}{ Building B } & Spring Lake proposed & $17 \%$ & $13 \%$ \\
& Target ZERH & $4 \%$ & $15 \%$ \\
Building C & Spring Lake proposed & $18 \%$ & - \\
& Target ZERH & $10 \%$ & $14 \%$ \\
Building D & Spring Lake proposed & $23 \%$ & - \\
& Target ZERH & $10 \%$ & - \\
Building E & Spring Lake proposed & $23 \%$ & $14 \%$ \\
\hline
\end{tabular}

Table 3 compares the energy-efficiency specifications that were applied to this project to the prescriptive requirements under California's 2013 Title 24 energy code. Specific measures are discussed in the sections that follow the table.

${ }^{9}$ Given limitations in the Title 24 software, building infiltration could not be modeled. 
Table 3. Energy-Efficiency Measure Specifications

\begin{tabular}{|c|c|c|}
\hline Measure & $\begin{array}{c}\text { Base Case: Title } 24 \text { Prescriptive } \\
\text { Measures }\end{array}$ & Spring Lake Specifications \\
\hline \multicolumn{3}{|c|}{ Envelope } \\
\hline Exterior Wall Construction & $2 \times 6 \mathrm{R}-1916$ in. o.c. & $2 \times 6 \mathrm{R}-2116$ in. o.c. \\
\hline Foundation Type and Insulation & Slab, uninsulated & Slab, uninsulated \\
\hline Roof Insulation & R-38@ ceiling in vented attic & $\begin{array}{c}\text { R-44 (flats) R-49 (townhomes) @ ceiling in } \\
\text { vented attic }\end{array}$ \\
\hline Roofing Material & $\begin{array}{l}\text { Comp shingles, } \mathrm{CRRC}^{\mathrm{a}} \text { certified, with } \\
\text { radiant barrier sheathing }\end{array}$ & $\begin{array}{l}\text { Comp shingles and single ply roofing, both } \\
\text { CRRC certified, with radiant barrier sheathing }\end{array}$ \\
\hline House Infiltration & $7 \mathrm{ACH} 50$ & $4 \mathrm{ACH} 50$ \\
\hline Glazing & $\mathrm{U}$-value $=0.40, \mathrm{SHGC}^{\mathrm{c}}=0.40$ & $\begin{aligned} \text { Single Hung Windows: } U & =0.29, \text { SHGC }=0.19 \\
\text { Sliding Glass Doors: } U & =0.29, \text { SHGC } 0.23\end{aligned}$ \\
\hline $\begin{array}{c}\text { Thermal Enclosure } \\
\text { Checklist/Quality Insulation } \\
\text { Installation }\end{array}$ & No & 然 \\
\hline \multicolumn{3}{|c|}{ HVAC Equipment } \\
\hline $\begin{array}{l}\text { Heating/Cooling System Type and } \\
\text { Efficiency }\end{array}$ & $\begin{array}{l}\text { Single-speed heat pump: seasonal } \\
\text { energy-efficiency ratio } 13 \text {, heating } \\
\text { seasonal performance factor } 7.7\end{array}$ & $\begin{array}{c}\text { Altherma air-to-water inverter-driven heat pump: } \\
\text { seasonal energy-efficiency ratio } 13 \text {, heating } \\
\text { seasonal performance factor } 11\end{array}$ \\
\hline Heating/Cooling Distribution & $\begin{array}{c}\text { R-6 ducts located in attic, } 6 \% \text { duct } \\
\text { leakage }\end{array}$ & $\begin{array}{l}\text { Conditioned space: Dropped soffits (flats). R- } 8 \\
\text { ducts buried under min } 3-1 / 2-\text {-in. blown insulation } \\
\text { (townhomes) }\end{array}$ \\
\hline Mechanical Ventilation & Exhaust fans per ASHRAE 62.2 & ENERGY STAR exhaust fans per ASHRAE 62.2 \\
\hline \multicolumn{3}{|c|}{ Water Heating Equipment } \\
\hline Water Heater Type and Efficiency & Gas storage: 0.575 energy factor & Altherma heat pump: 2.4 energy factor \\
\hline \multicolumn{3}{|c|}{ Appliances and Lighting } \\
\hline ENERGY STAR Appliances & None & Dishwasher and refrigerator \\
\hline Lighting Package & $\begin{array}{l}\sim 50 \% \text { fluorescent, } \sim 50 \% \text { incandescent } \\
\text { with occupancy or dimmer controls }\end{array}$ & $\begin{array}{c}\text { Mix of fluorescent fixtures and LED }{ }^{b} \text { ENERGY } \\
\text { STAR A-base lamps }\end{array}$ \\
\hline Energy Feedback Device & None & Canary Instruments energy monitor \\
\hline
\end{tabular}

\footnotetext{
${ }^{a}$ Cool Roof Rating Council, ${ }^{b}$ Light-emitting diode, ${ }^{\mathrm{c}}$ Solar heat gain coefficient
} 


\subsubsection{Exterior Walls}

Exterior walls were framed using $2 \times 6$ studs 16 in. o.c. with high-density R-21 fiberglass batt.

Structural requirements precluded the use of such advanced framing techniques as 24 in. o.c. spacing, but corners were insulated to minimize thermal shorts, and other requirements of the ENERGY STAR Thermal Enclosure System Checklist item 4.4.5 were followed. Intersecting interior walls were secured to exterior walls by framing in a $2 \times 6$ stud with its $5-1 / 2$-in. dimension flush with the interior plate as shown in Figure 3.

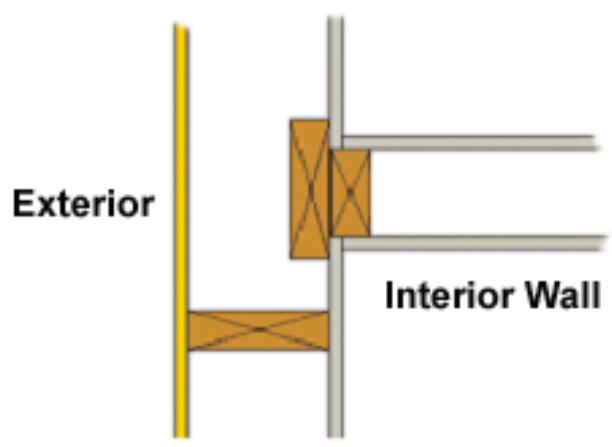

Figure 3. Attaching intersecting walls using a flat $2 \times 6$ stud instead of ladder blocking provides a nailing surface for drywall.

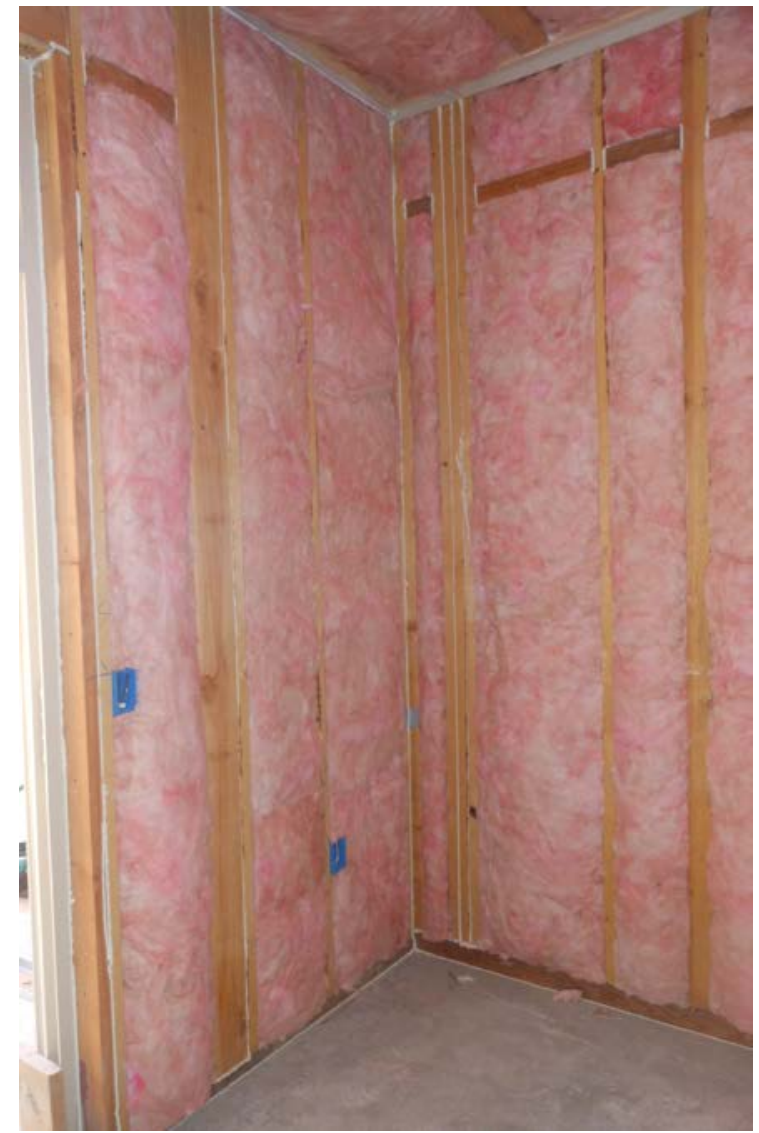

Figure 4. Quality wall insulation installation

In practice, batt insulation is typically much more prone to defects such as voids and compression than blown or foam insulation. Even though blown-in fiberglass wall insulation is more costly per unit area than batts, installed costs can be comparable after the additional labor costs that are required to correct the installation defects are factored in. Despite ARBI's recommendation to use blown-in insulation, the insulation contractor chose to use standard batt insulation. The HERS rater met with the project team when site work was underway to discuss the quality installation expectations, and the HERS rater regularly visited the site during all stages of construction to conduct incremental inspections and provide feedback along the way. The insulation contractor did an impressive job on the first attempt (see Figure 4).

\subsubsection{Ceiling and Roof}

The townhomes and apartments have vented attic spaces with blown insulation at the ceiling plane to achieve R-49. Raised heel trusses 18 in. high at the plate lines were installed in the townhomes to increase the depth of insulation along the perimeter. This was difficult to accomplish in the apartments (flats); therefore, to meet the ENERGY STAR requirement that insulation at the attic perimeter be at minimum R-21, 4 in. of rigid insulation was placed between the trusses and extended $2 \mathrm{ft}$ inward from the exterior wall. An attic radiant barrier was also installed to reduce radiant heat transfer into the attic. These details are pictured in Figure 5. All 
roofing is CRRC certified. Initial solar reflectance is 0.83 for single-ply roofing over flat areas and 0.26 for composition shingle on sloped roofs.
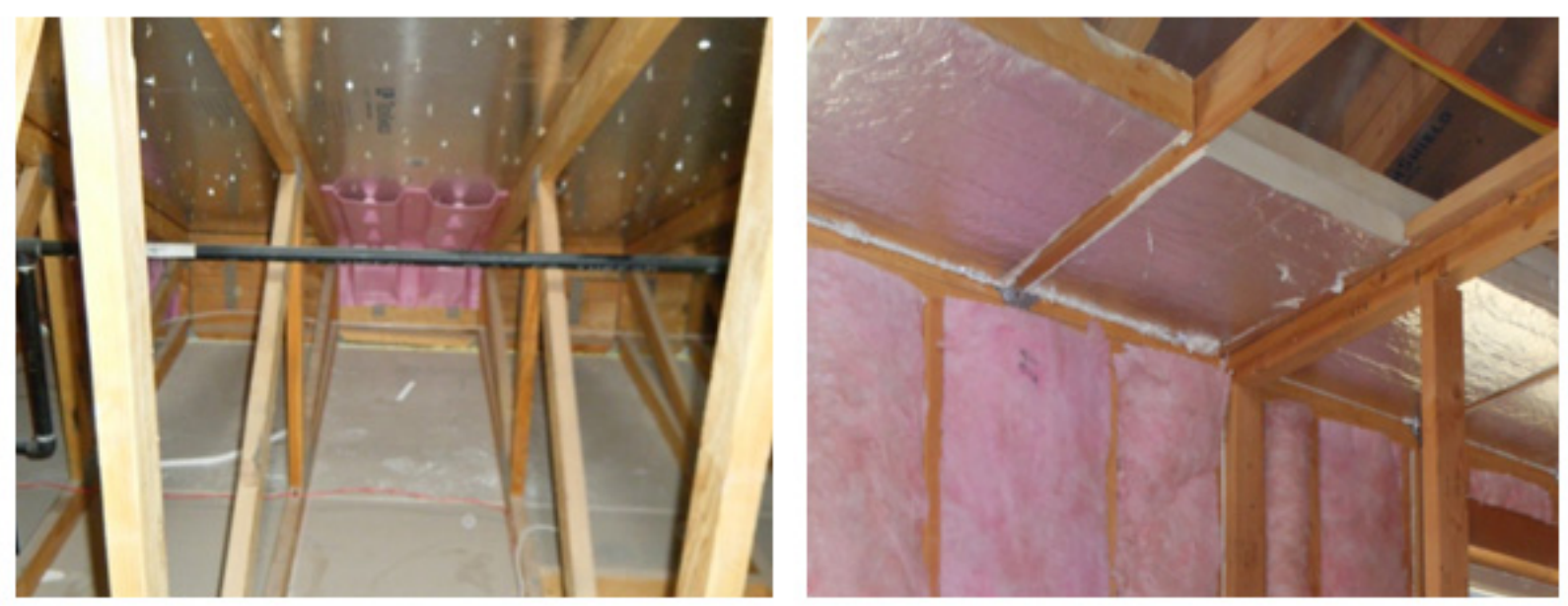

Figure 5: Raised heel trusses in townhomes (left); rigid insulation in apartment building (right)

\subsubsection{Glazing}

The windows and sliding glass doors were manufactured by Alside and are a vinyl-frame, dualglazed, argon-filled product that meets ENERGY STAR certification requirements. The U-value is 0.29 and the SHGC is 0.19 for the windows and 0.23 for the doors.

\subsubsection{Air Sealing}

Although a moisture barrier was installed on exterior walls, no air barrier was installed at the party walls and the builder opted to use the interior drywall as the air barrier. Air sealing was completed in accordance with Section 5 of the ENERGY STAR Thermal Enclosure System Rater Checklist. To minimize leakage through boxes for electrical outlets, switches, and communications wiring, boxes were either wrapped with fire-resistive "putty pads" (required at fire-rated walls) or wire penetrations were foamed; boxes were caulked to the drywall. To test the effectiveness of the air-sealing strategies, multiple sequential blower door tests were completed on prototype townhouse and flat units following each improvement to identify and remediate problematic leakage points.

Despite efforts to provide thorough sealing, the $3 \mathrm{ACH} 50$ required under the mandatory requirements of the California ZERH program could not be attained. Upon conferring with Newport Partners an adjustment to the airtightness requirement was made that increased the maximum allowable leakage rate for multifamily buildings to $4 \mathrm{ACH} 50$. This change was supported by experience with multifamily buildings in other states, and resulted in the following revised language in the California specifications (DOE 2014):

For all CA Climate Zones 1-16, must be tested to achieve air infiltration levels at or below: $3 \mathrm{ACH} 50$ for single-family detached dwellings, or $4 \mathrm{ACH} 50$ for attached single-family dwellings and dwellings in multifamily buildings. 
The probable sources of leakage that prevented reaching the 3 ACH50 level include gaps at fire sprinklers and leakage at rim joists that allowed air to infiltrate through cracks in subfloors and stairs. This topic is covered in greater detail in Section 4.

\subsubsection{HVAC and Domestic Water Heating Systems}

The mechanical consultant selected Daikin Altherma air-to-water split-system heat pumps to provide space heating and cooling as well as water heating. The advantages to these systems include (1) simplification - they use a single system to serve all heating and cooling needs — and (2) elimination of long refrigerant lines, natural gas piping, and combustion venting. The Altherma is effectively a split-system heat pump water heater with an outdoor evaporator, so it eliminates the need for large interior spaces that such systems typically require. One unit is installed for each townhouse and flat and hot water storage tanks are provided at each unit to eliminate losses from hot water recirculation piping.

The Altherma is an inverter-driven variable-speed system that is available either as a single package "monoblock" or a split system. The split system, which connects the outdoor unit to an indoor "hydrobox," was employed in this project. The hydrobox contains a refrigerant-to-water heat exchanger, pump, expansion tank, and other components that are typically required for hydronic systems. The heat exchangers are piped to fan coil units installed in closets within each unit. The outdoor unit is pictured in Figure 6, which also shows a water heater closet with the storage tank and hydrobox installed.
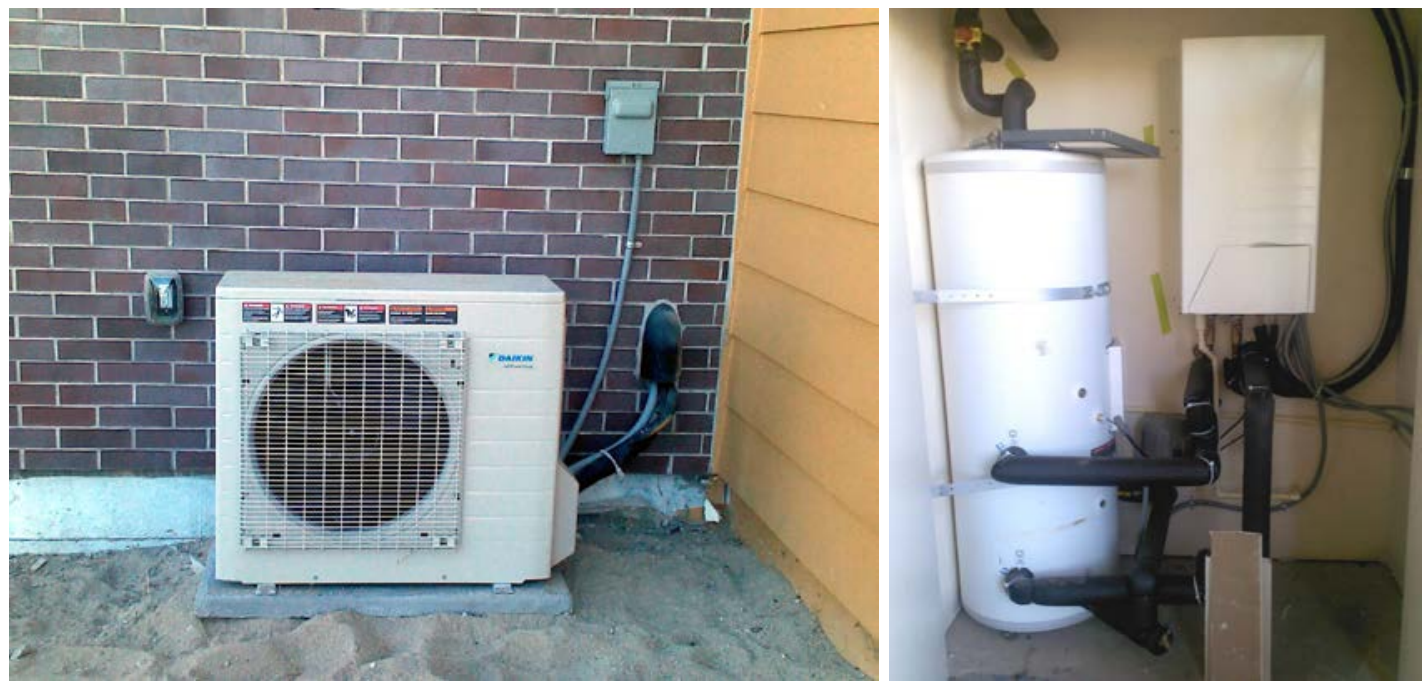

Figure 6. Altherma outdoor unit (left); water heater closet with storage tank and hydrobox (right)

In the apartment flats the ductwork is located entirely within conditioned space. After drywall was installed and taped, hallway ceilings were furred down with steel framing and R-4.2 ducting was installed. Ducting punches through the drywall supply sidewall registers in the rooms and is sealed to the drywall (see Figure 7). In the townhouses the supply ductwork for the first floor is located between floors and for the second floor it is in the attic. Attic ductwork is deeply buried beneath a minimum of $3-1 / 2$ in. of blown insulation and leakage to outside is tested to not exceed $3 \mathrm{CFM}$ at $25 \mathrm{~Pa}$ per $100 \mathrm{ft}^{2}$ of conditioned floor area. ARBI worked with Newport Partners and DOE to clarify that this requirement references leakage to outside instead of total leakage, 
because leakage to outside is the primary metric of concern with allowing ductwork to be buried in a vented attic.
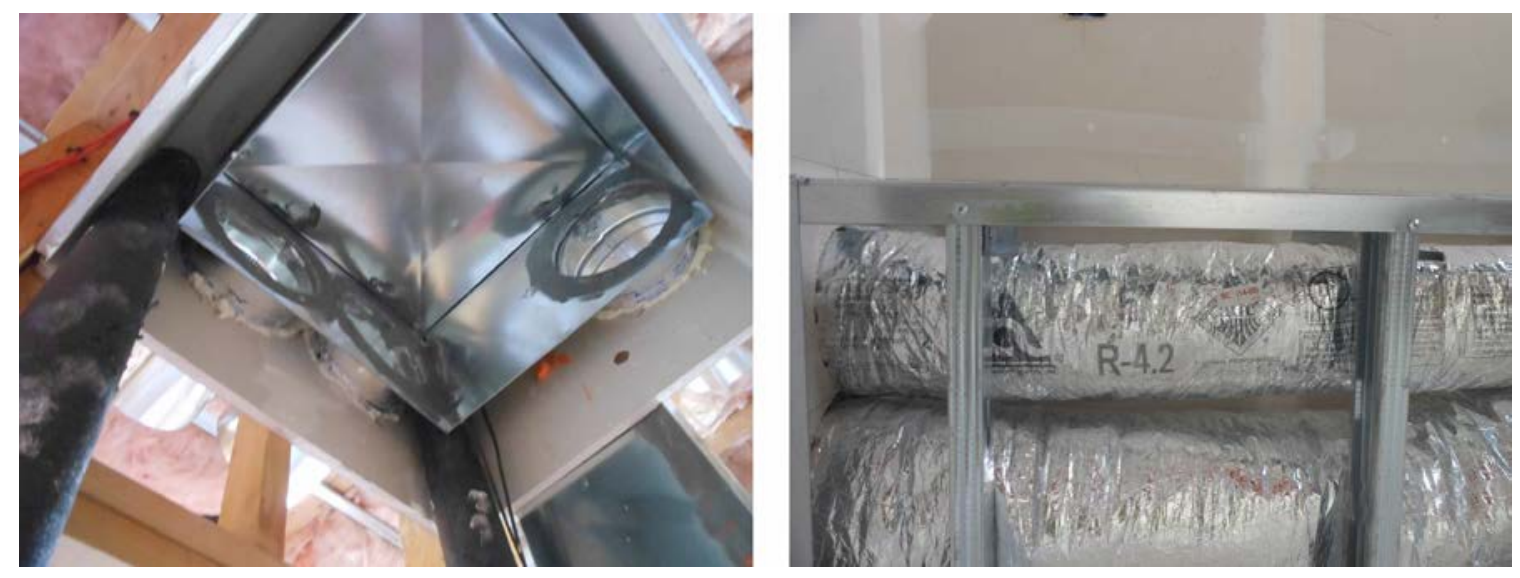

Figure 7. Supply plenum in mechanical closet (left); ducts in furred hallway ceiling (right) 


\section{Results and Discussion}

\subsection{Performance Inspections and Testing}

Testing to verify that the project met the required performance targets for Title 24, ENERGY STAR, and ZERH was initiated in January 2015 and was completed in early March. The targets for the major tests, including duct leakage, building infiltration, and HVAC system airflow, are presented in Table 4, which lists measured total duct leakage and duct loss to outside at $25 \mathrm{~Pa}$ pressurization, and whole unit leakage (infiltration) at $50 \mathrm{~Pa}$.

Table 4. Project Performance Testing Targets

\begin{tabular}{|c|c|c|c|c|c|c|c|c|}
\hline \multirow[b]{2}{*}{ Unit Type } & \multirow[b]{2}{*}{ Quantity } & \multirow[b]{2}{*}{ CFA } & \multirow[b]{2}{*}{$\begin{array}{c}\# \\
\text { Beds }\end{array}$} & \multirow[b]{2}{*}{$\begin{array}{l}\text { A/C } \\
\text { Size }\end{array}$} & \multicolumn{4}{|c|}{ Performance Targets } \\
\hline & & & & & $\begin{array}{l}\text { Cooling } \\
\text { Airflow } \\
(\mathrm{CFM})^{\mathrm{a}}\end{array}$ & $\begin{array}{c}\text { Total } \\
\text { Duct } \\
\text { Leakage } \\
\text { (CFM25) }\end{array}$ & $\begin{array}{c}\text { Duct Loss } \\
\text { to } \\
\text { Outside } \\
\text { (CFM25) }\end{array}$ & $\begin{array}{c}\text { Infiltration } \\
\text { (CFM50) }^{d}\end{array}$ \\
\hline A-Flat & 12 & 709 & 1 & 1.5 & 600 & 57 & 35 & 425 \\
\hline B - Flat & 20 & 929 & 2 & 1.5 & 600 & 74 & 46 & 557 \\
\hline C - Flat & 12 & 1,082 & 3 & 1.5 & 600 & 87 & 54 & 649 \\
\hline D - Flat & 6 & 1,287 & 4 & 2 & 800 & 103 & 51 & 772 \\
\hline E - Townhouse & 4 & 1,360 & 3 & 2.5 & 1,000 & 60 & 41 & 816 \\
\hline F - Townhouse & 2 & 1,515 & 4 & 2.5 & 1,000 & 60 & 45 & 909 \\
\hline G-Townhouse & 6 & 1,390 & 3 & 2.5 & 1,000 & 60 & 42 & 834 \\
\hline
\end{tabular}

${ }^{\mathrm{a}}$ Specifications from mechanical consultant based on equipment selected and buildings loads.

${ }^{\mathrm{b}}$ The lower of the Title 24 and ENERGY STAR requirement. Duct leakage credit for Title 24 was applied to the townhouses ( $\leq 6 \%$ of system airflow). Total duct leakage target at the flats was based on the ENERGY STAR requirement of 8 CFM 25 per $100 \mathrm{ft}^{2}$ of CFA.

${ }^{\mathrm{c}}$ The flats were required to meet the ENERGY STAR requirement of 4-5 CFM25 (based on CFA) per $100 \mathrm{ft}^{2}$ of CFA. The townhouses were held to the more stringent requirement of 3 CFM25 per $100 \mathrm{ft}^{2}$ of CFA based on the ZERH maximums for buried ducts.

${ }^{\mathrm{c}}$ Based on 4 ACH50.

Final test results for duct leakage and building infiltration are presented in Figure 8 and Figure 9, respectively; a discussion of some of the challenges encountered in meeting them follows. All the townhouse units were tested because only 12 were built. HERS sampling protocols were followed for the apartment flats. (The vertical bars represent the range of results and the dots are the mean.) 


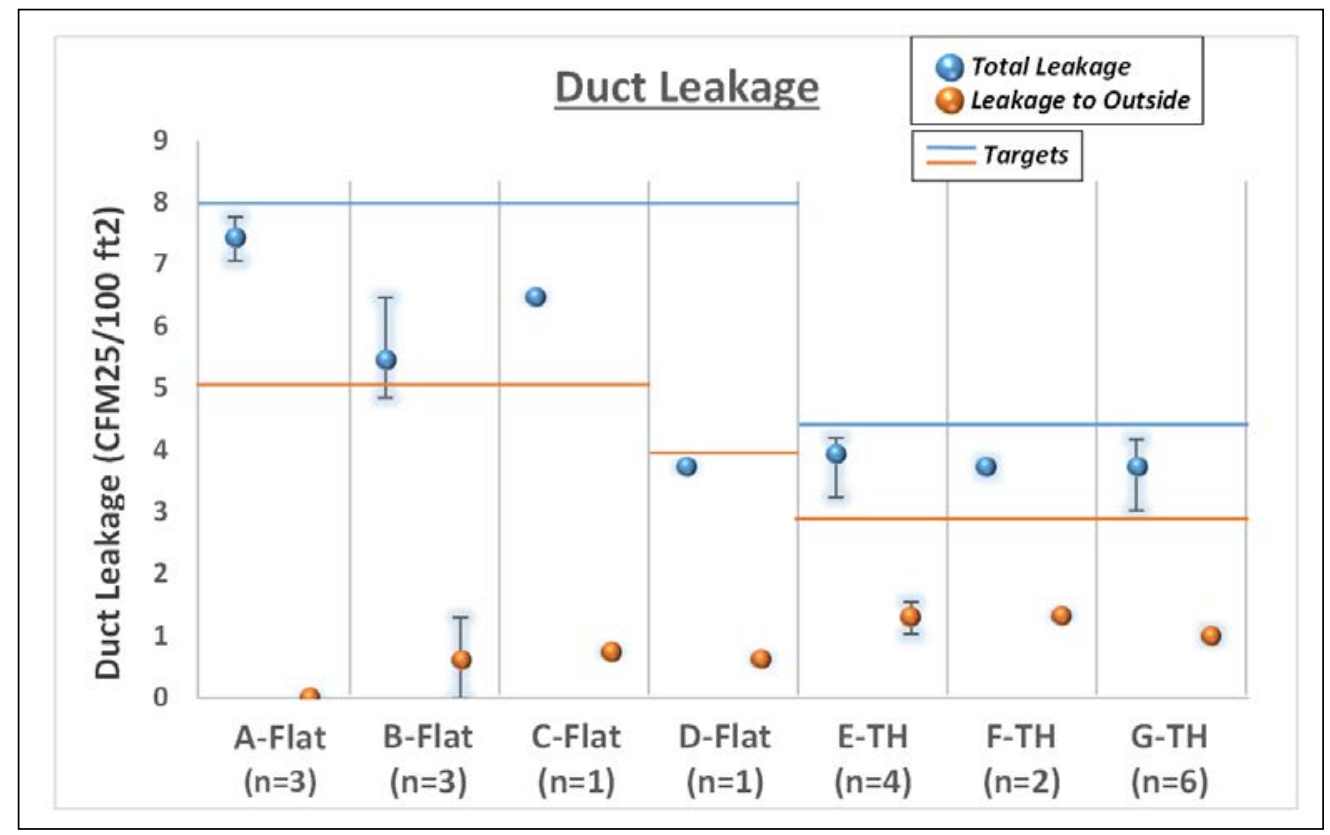

Figure 8. Results of duct leakage testing

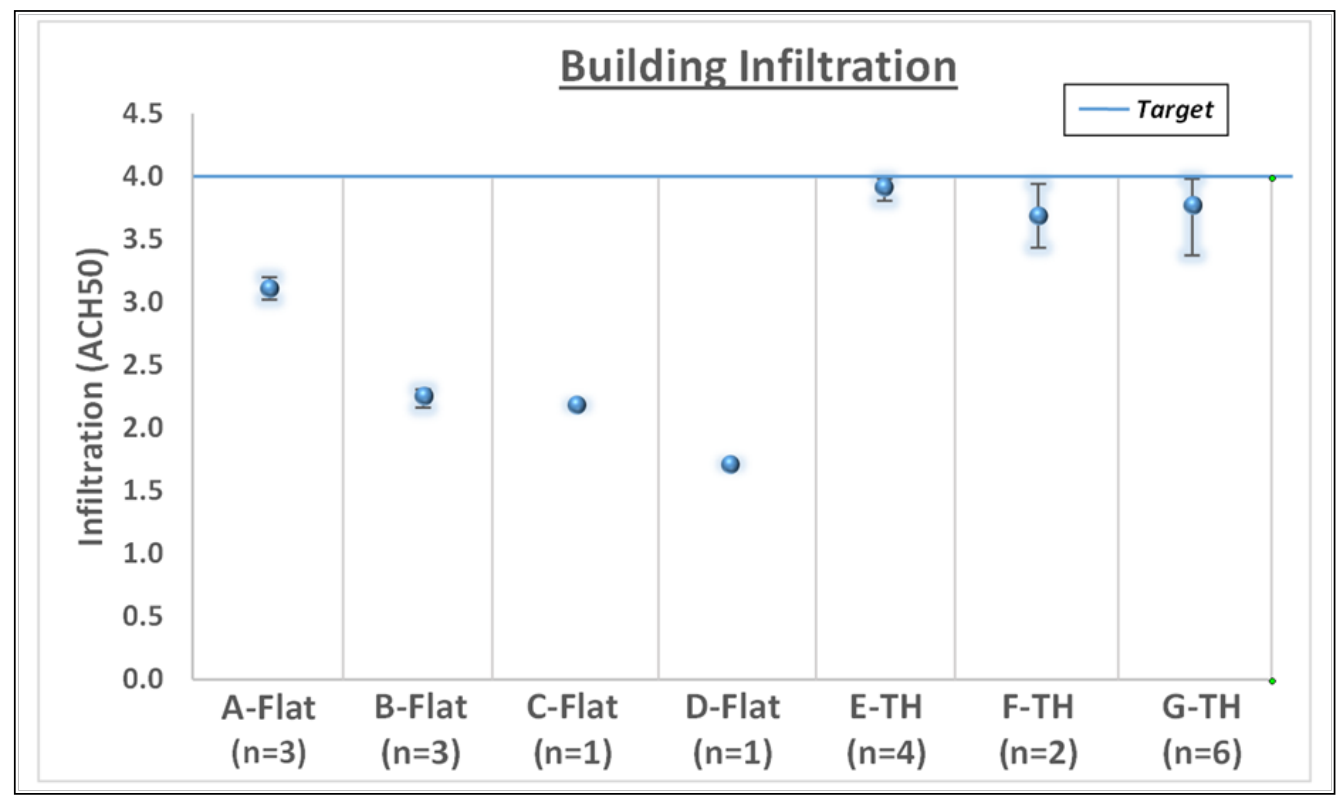

Figure 9. Results of building infiltration testing

\subsection{Construction Process and Challenges}

Early in the construction process the builder completed two prototypes, one for each unit type (apartments and townhomes). ARBI/DEG conducted a sample of HERS inspections and performance testing on these two units. This process identified and resolved certain issues (see Section 4.2.1 through Section 4.2.4). 


\subsubsection{Reduced Building Infiltration}

ARBI/DEG conducted four blower door tests at the townhouse mockup before reaching the design leakage targets. At the initial test the HVAC system was in the rough-in stage (no air handlers were installed) and window sills and some electrical outlets and sprinkler covers were not installed. Measured infiltration was 4.8 ACH50. ARBI reviewed all of the potential sources of leakage when drywall is used as the primary air barrier. The builder had thoroughly sealed the bottom plates to the foundations with foam and caulking, and all penetrations of plates by wiring and plumbing were caulked. Electrical boxes were identified as a large source of leakage, particularly in exterior walls. Boxes that were not wrapped with fireproof "putty pads" (see Figure 10) were sealed with foam. A double seal was provided to seal attic access hatches, and drywall gaps in the mechanical closets were plugged with foam.

After multiple measures were implemented to block leakage points and after HVAC ducting and the air handler were installed, testing of the townhouse mockup unit showed the leakage rate to be no lower than 3.7 ACH50. Newport Partners had seen difficulties with reaching the 3 ACH50 target with other multifamily units and modified the California specification to allow 4 ACH50.
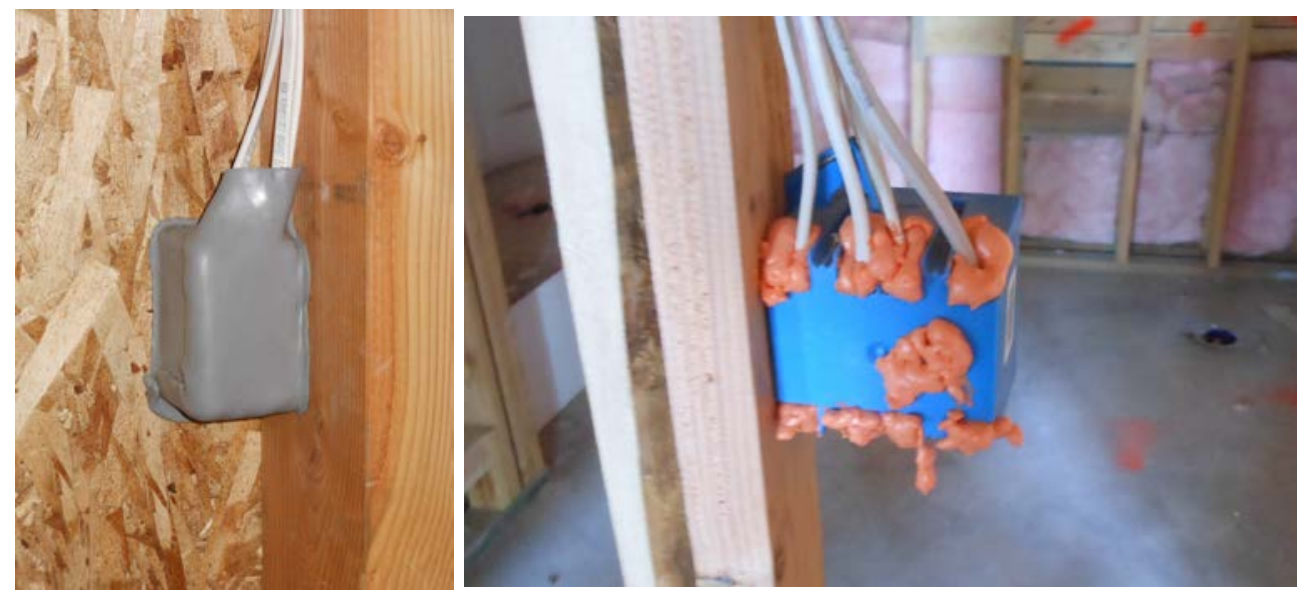

Figure 10. Methods used to seal electrical boxes at exterior walls (left); interior walls (right)

Blower door tests that were completed after the floor coverings were installed revealed another source of leakage. The floor coverings had been covered with protective plastic. Ballooning of the plastic during depressurization revealed that air was leaking past seams in the subfloor, particularly at gaps in the flooring at stairwells. The ultimate source of the leakage was apparently through inadequately sealed rim joists at the perimeter of the townhouse unit (see Figure 11). Final blower door testing demonstrated that all units met the 4 ACH50 target but with little room for error. The additional air sealing conducted as a result of lessons learned during mockup testing was crucial to ensure a $100 \%$ compliance rate. 

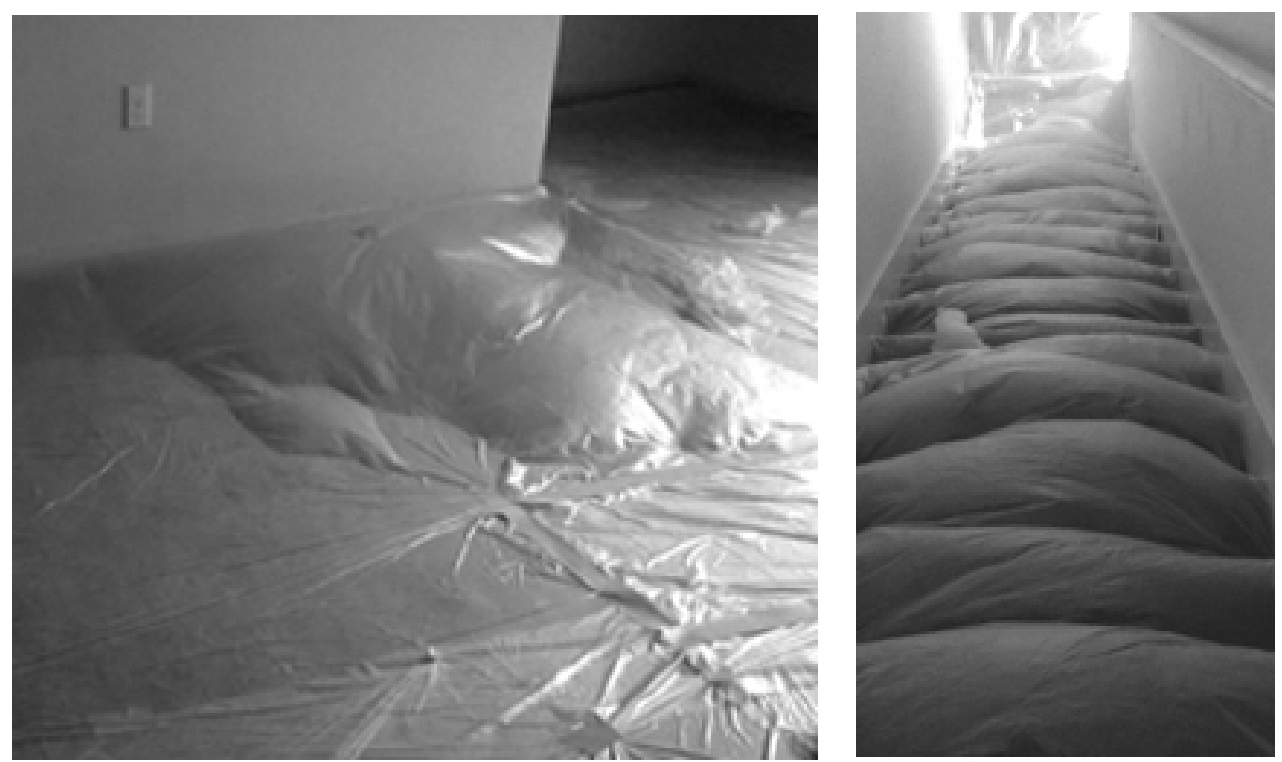

Figure 11. Leakage through subfloor (left); stairs in townhouse unit evident during depressurization (right)

The apartment mockup was completed and tested toward the end of the townhouse testing and met the 4 ACH50 target after the initial test. Sources of leakage were identified around unsealed electrical boxes, the bathtub, dryer duct, and at the wall-floor junctions. ARBI recommended that more diligent efforts be made in subsequent units to better air seal these locations even though the target had been met. The final blower door tests showed very little unit-by-unit variability; most of the units were lower than $3 \mathrm{ACH} 50$.

\subsubsection{Fresh Air}

Plans called for use of continuously operating bathroom fans to meet ASHRAE 62.2. As is fairly common practice and in accordance with plans, the HVAC contractor installed outside air ducts that were connected to return plenums to provide a direct source of outside air. Provisions were made for small filters to filter outside air that were accessible through the return air filter grilles. The outside air ducts were not detected until they were observed on the initial visit to test duct leakage. Because they were neither dampered nor designed to operate intermittently as required by the ENERGY STAR Installation Contractor Checklist item 1.2, and the opening made it impossible to comply with duct and building leakage requirements, the openings were taped off during testing and the HVAC contractor was asked to permanently block them with sheet metal. Testing of the exhaust fan flows revealed sufficient airflow to meet 62.2 requirements without the ducted outside air. Providing a filtered source of outside air from a known location may improve indoor air quality, and this strategy deserves consideration for future ENERGY STAR updates.

\subsubsection{Duct Leakage}

Duct leakage testing was initially specified as a HERS measure for Title 24 credit for the townhouses but not the apartments. The HVAC contractor mistakenly thought that because the ducts were within conditioned space in the flats no duct testing was required. Thus, less care was 
taken to seal the ductwork in the dropped soffits in the flats than in the townhomes, which included attic ducting and HERS-verified duct leakage for Title 24. ENERGY STAR does not exempt ducts in conditioned space from testing, and additional Title 24 credit could be claimed for verifying duct leakage. Because the total leakage (as a result of excessive leakages to the inside) exceeded the maximum $6 \%$ of system airflow required for the Title 24 measure, testing was completed using the "leakage to outside" method, which allows no more than 25 CFM25 leakage to outside. All the apartments met the ENERGY STAR total and duct leakage to outside targets and the Title 24 leakage to outside requirements.

Initial testing of the townhouse mockup showed duct leakage of 94 CFM25, which is higher than the allowable maximum of 60 CFM25. ${ }^{10}$ An inspection of the units revealed that a major contributor to leakage was poor sealing between the plenum and the air handler. Narrow clearances in the mechanical closet made sealing this intersection very difficult. At this time the team also recommended checking all the joints in the attic to minimize duct leakage to outside. After some additional sealing was done the team returned and tested total leakage at 54 CFM25 of system airflow and leakage to outside at 19 CFM25, well below the allowed 45 CFM25.

Another source of significant leakage at the townhomes and flats was the air handler. During testing the indoor mechanical closets were pressurized and there was significant air leakage around the doors, which were not weather-stripped. The mechanical contractor sealed the leaks in the air handlers at pipe connections and access panel seams before he recorded the leakage rates. The city building inspector requested that the contractor return to replace the masking tape with butyl backed aluminum tape. This is undesirable from the contractor's standpoint because this tape makes removal of panels for service access very difficult. A compromise position was to use aluminum tape that is easier to remove. A preferred alternative solution for future projects is to use a low-leakage air handler.

\subsubsection{HVAC Sizing}

The Altherma heat pump presented a challenge with following the ACCA Manual S guidelines. The system was sized using Daikin's proprietary sizing software, which takes into account the water heating loads that the system will provide in addition to the space-conditioning loads, which are calculated according to ACCA Manual J. Thus, ACCA Manual S could not be directly used for sizing. Instead, the manufacturer's recommendations were followed. Secondly, because inventory of the smaller capacity Altherma split systems was limited, the 2.5-ton units were used in place of 1.5 or 2-ton at the larger townhomes. However, the variable capacity of the Altherma allows the system to modulate down close to $5,000 \mathrm{Btu} / \mathrm{h}$ output, which is expected to alleviate any issues related to oversizing. ${ }^{11}$

When ARBI obtained the ACCA Manual J reports that were completed by the mechanical consultant, it was found that incorrect design temperatures had been used and calculations did

\footnotetext{
${ }^{10}$ Based on the $6 \%$ of nominal system airflow for Title 24 . Total leakage was actually under the ENERGY STAR total leakage requirement of 8 CFM25 per $100 \mathrm{ft}^{2}$ of CFA.

${ }^{11}$ Altherma was decertified with the adoption of the 2013 Title 24 code and currently Aermec manufactures the only certified air-to-water heat pump product. The Altherma representative indicated that new models that will be released in 2016 will be tested as required under the 2013 code. Increased competition in this product area would likely lower costs.
} 
not include loads for worst-case unit orientations. In some cases the room-by-room airflows differed from what was shown in the ACCA Manual J report. The mechanical consultant made these corrections, but ducts had been sized in accordance with airflow rates listed in the drawings. The contractor was able to successfully balance airflows to meet the revised ACCA Manual J requirements, but this episode highlighted the importance of making the mechanical consultant and contractor aware of program requirements and of having sufficient communications between team members throughout a project, especially when changes are made.

\subsection{Incremental Costs and Cost-Effectiveness}

Table 5 presents the incremental costs of the measures that are required for the project to achieve ZERH and LEED certification and to meet its zero energy design goal. Total costs slightly exceeded $\$ 8,000\left(\$ 7.91 / \mathrm{ft}^{2}\right)$ per unit before PV and $\$ 19,000\left(\$ 18.54 / \mathrm{ft}^{2}\right)$ including PV. This is higher than ARBI has observed for other multifamily projects, which often can achieve a lower cost basis per square foot relative to single-family projects from economies of scale (German et al. 2014). The major contributors to costs were the Altherma air-to-water heat pump system and the lighting package, which together represented $74 \%$ of the total incremental cost for all energyefficiency measures. While there are lower-cost alternatives to the Altherma, they are not currently approved for California under the Title-24 energy code. Even the Altherma has been decertified since this project was approved due to a change in the 2013 standards, leaving an even more expensive heat pump as the only certified product.

At more than $\$ 1,700$ incremental cost per unit the light-emitting diode (LED) fixtures were significantly costlier than would be expected, particularly relative to the current 2013 Title-24 energy code, which requires a lighting package very similar to what was installed at Spring Lake (which was built under the 2008 code). LED or CFL lighting will be universally code-required in California beginning 2017.

The cost for air sealing was higher than it could have been because much of the sealing that was necessary was funded by change orders instead of as part of the original bid. The same is true for the necessary door return air vents that were not anticipated by the plans and specifications. If jump ducts or transfer grilles had been installed at the time of construction rather than after testing identified the need, the cost would likely have been much lower. 
Table 5. Incremental Costs of ZERH and LEED Measures

\begin{tabular}{|c|c|c|c|c|c|c|}
\hline Measure & $\begin{array}{c}\text { Base: T-24 } \\
\text { Prescriptive }\end{array}$ & $\begin{array}{c}\text { Spring Lake } \\
\text { Specifications }\end{array}$ & $\begin{array}{c}\text { Standard } \\
\text { Cost }\end{array}$ & $\begin{array}{c}\text { Actual } \\
\text { Cost }\end{array}$ & \multicolumn{2}{|c|}{ Incremental Cost } \\
\hline \multicolumn{7}{|c|}{ Envelope } \\
\hline Exterior Wall Construction & $2 \times 6$ R-19 16 in. o.c. & $2 \times 6$ R-21 16 in. o.c. & $\$ 21,435$ & $\$ 28,121$ & $\$ 6,686$ & $\$ 0.13 / \mathrm{ft}^{2}$ wall \\
\hline Ceiling Insulation@ Vented Attic & $\mathrm{R}-38$ & $\mathrm{R}-49$ & $\$ 22,580$ & $\$ 28,276$ & $\$ 5,696$ & $\$ 0.22 / \mathrm{ft}^{2}$ ceiling \\
\hline House Infiltration & $7 \mathrm{ACH} 50$ & $4 \mathrm{ACH}_{50}$ & $\$ 0$ & $\$ 22,994$ & $\$ 22,994$ & $\$ 0.36 / \mathrm{CFA}$ \\
\hline Glazing (U-value/SHGC) & $0.40 / 0.40$ & $\begin{array}{c}\text { Windows: } 0.29 / 0.19 \\
\text { Glass door: } 0.29 / 0.23\end{array}$ & $-{ }^{12}$ & - & $\$ 8,600$ & $\begin{array}{l}\$ 1.51 / \mathrm{ft}^{\wedge} 2 \\
\text { window }\end{array}$ \\
\hline Thermal Enclosure Checklist & No & Yes & $\$ 0$ & $\$ 3,400$ & $\$ 3,400$ & \$54.84/apt \\
\hline \multicolumn{7}{|c|}{ HVAC Equipment } \\
\hline Heating/Cooling System & $\begin{array}{l}\text { 1-speed air-to-air } \\
\text { heat pump }\end{array}$ & $\begin{array}{l}\text { Altherma air-to-water heat } \\
\text { pump }\end{array}$ & $\$ 141,196$ & $\$ 405,304$ & $\$ 264,108$ & $\$ 4,260 / a p t$ \\
\hline Heating/Cooling Distribution & Ducted & Ducted & $\$ 349,816$ & $\$ 349,816$ & $\$ 0$ & $\$ 0$ \\
\hline Mechanical Ventilation & Std exhaust fans & ENERGY STAR exhaust fans & $\$ 17,136$ & $\$ 29,084$ & $\$ 11,948$ & $\$ 107 /$ fan \\
\hline ENERGY STAR HVAC Contractor Checklist & No & Yes & $\$ 0$ & $\$ 21,867$ & $\$ 21,867$ & $\$ 353 /$ apt \\
\hline Return Air Pathway Vents at Bedrooms & No & Yes & $\$ 0$ & $\$ 28,508$ & $\$ 28,508$ & $\$ 460 /$ apt \\
\hline \multicolumn{7}{|c|}{ Water Heating Equipment } \\
\hline Water Heater Type and Efficiency & $\begin{array}{l}\text { Gas storage: } 0.575 \\
\text { energy factor }\end{array}$ & Altherma $^{13}$ & $\$ 67,300$ & $\$ 86,956$ & $\$ 19,656$ & \$317/apt \\
\hline Shower Heads & Standard: 2.0 gpm & $\begin{array}{l}\text { Evolve: } 1.5 \mathrm{gpm} \text { unit with } \\
\text { warmup temp shutoff valve }\end{array}$ & - & - & $\$ 5,464$ & $\$ 48.79 /$ fixture \\
\hline \multicolumn{7}{|c|}{ Appliances and Lighting } \\
\hline ENERGY STAR Appliances & None & Dishwasher and refrigerator & - & - & $\$ 6,200$ & $\$ 100 /$ apt \\
\hline Lighting Package & $\begin{array}{l}\sim 1 / 2 \text { fluorescent, } \\
\text { controls per Title } 24\end{array}$ & $\begin{array}{l}\text { Mix of fluorescent fixtures } \\
\text { and LED A-lamp bulbs }\end{array}$ & $\$ 81,600$ & $\$ 187,800$ & $\$ 106,200$ & $\$ 1,713 /$ apt \\
\hline \multicolumn{7}{|c|}{ On-Site Generation } \\
\hline PV System & None & 209-kW DC system & $\$ 0$ & $\$ 686,532$ & $\$ 686,532$ & $\$ 3,284 / \mathrm{kW}^{14}$ \\
\hline \multicolumn{5}{|c|}{ Total Project Incremental Cost $(+P V)$ : } & $\begin{array}{r}\$ 511,327 \\
\$ 1,197,859\end{array}$ & $\begin{array}{c}\$ 8,247 / \text { apt } \\
\$ 7.91 / \text { CFA } \\
\$ 19,320 / \text { apt } \\
\$ 18.54 / \text { CFA }\end{array}$ \\
\hline
\end{tabular}

\footnotetext{
${ }^{12}$ Project team provided incremental costs but not "standard" and actual (or estimated) costs for certain measures.

${ }^{13}$ Reflects the cost for the hot water storage tank only, the heat pump costs are included within the heating/cooling system.

${ }^{14}$ Includes a $\$ 1.33 / \mathrm{W}$ rebate for the PV system.
} 


\section{Conclusions and Recommendations}

\subsection{Developer Feedback}

This project was the developer's first attempt at building to ZERH and zero energy standards, although it has been building above code and certifying projects through California's Build It Green program for the past 7 years. Mutual Housing expressed that the most difficult aspect of this project was fully understanding all the performance specifications and ensuring that all the team members were on board and had a clear understanding of what needed to be done. Some of these challenges could have been alleviated if ZERH requirements had been fully understood and incorporated into the bid documents. Also, this was the first attempt by a multifamily developer to obtain ZERH certification, and other project examples were not available to follow. Mutual Housing is committed to developing a thorough understanding of all requirements and to communicating those requirements to the design team, consultants, contractors, installers, and verifiers in future projects. Even with these challenges, Mutual Housing considers this project a success and plans to build more projects to the ZERH standard.

\subsection{The Importance of Communication}

Communication between the ZERH verifier (in this case ARBI) and the developer, design team, and construction staff was found to be critical. Only through a solid commitment and ongoing dedication on the part of Mutual Housing and the builder, Sunseri Construction, were early oversights (which could have sidetracked the ZERH certification) addressed and overcome.

The developer, contractor, and critical subcontractors attended a project team meeting before construction began to review ENERGY STAR and ZERH program requirements in detail. Nonetheless, ARBI learned that reminders of program requirements were needed through each stage of construction.

ARBI had minimal contact with the HVAC contractor before the installation work began, and no further discussion occurred about the details of the ENERGY STAR requirements until the team was preparing to conduct verifications. This was a mistake. The contractor had no questions during the initial team meeting, and although he was fairly new to ENERGY STAR, he had recently completed and certified another project in which DEG was involved. As the work was nearing completion, it became clear that the contractor did not understand that he would be obligated to complete the ENERGY STAR HVAC Contractor Checklist and had not been following its guidelines. It also became evident that communication disconnects had occurred between the contractor, mechanical consultant, and Title 24 energy consultant. The mechanical consultant had made updates to the ACCA Manual J sizing calculations that were not passed along to the HVAC contractor and were not in his scope. The energy consultant had also updated the Title 24 compliance documents when finalizing the zero net energy design without notifying the HVAC contractor. Meanwhile, the contractor continued to work under the original Title 24 compliance documents even though they had been altered numerous times. For example, the revised documents required that duct testing be conducted for all apartment units.

These experiences demonstrated that one person who thoroughly understands ENERGY STAR and ZERH checklists and requirements should be assigned to provide ongoing coordination of program requirements with the owner, architect, energy consultant, builder, HVAC and 
insulation contractors, and verifiers from design through construction. All participants need to be reminded of their responsibilities in a timely manner to avoid costly corrections and change orders. Communication initiated early on in the design process and maintained throughout the project is crucial to success of high-performance buildings, especially those that are built to ZERH standards.

\subsection{Project Management Recommendations}

Recommended steps for managing ZERH projects follow. Some of this scope may not be clearly defined under any team member's traditional roles. The responsibility for this scope should reside with a knowledgeable individual or entity that is an authorized representative of the owner from the initiation of design through the completion of construction. This team member should have ready access to the site and be included in communications with the entire design, construction, and HERS verification team.

The following steps are suggested for proper management of future multifamily ZERH projects:

1. Conduct a charrette or meeting with the owner/developer, architect, structural and mechanical consultants, energy code consultant, and general contractor (if selected) before or during the schematic design phase to introduce project performance requirements and discuss strategies for compliance.

2. Conduct a design review before the construction drawings are completed (for example, at $95 \%$ design development) to ensure that the plans and specifications cover all the required measures. A second review may be completed to verify that the bid documents adequately represent the contractor responsibilities. Identify and resolve noncompliance with checklist items or ambiguities. Discuss ALL these items with the responsible party to verify compliance and resolve noncompliance concerns.

3. Complete an energy code compliance review to ensure that no conflicts have arisen and to identify which requirements take precedence. For California projects Title 24 credit should be taken for any ENERGY STAR- and ZERH-required measures that can earn additional compliance points, Multi-family New Home program incentives, and Utility Allowance Calculator credits.

4. Before initiating construction, conduct a meeting with the contractor and all affected subcontractors to review the responsibilities of each subcontractor and provide custom checklists that detail the responsibilities of each trade as they relate to the specific project.

5. Include the person managing ZERH-related work in the lines of communication regarding revisions to plans and specifications and change orders that may affect energyefficiency measures and energy code compliance, and coordinate the changes with the architect, mechanical consultant, energy consultant, general contractor, and verifier as needed.

6. Regularly check in with individuals who are listed as the responsible parties for each checklist. Discuss how they will meet the requirements, identify who else they may be dependent on to complete their work, and help them remove any barriers. Work with the project team to provide solutions, encouragement, and resources for success. 
7. Conduct initial inspections and testing as early as possible to identify and resolve concerns. When possible, construct mockups (as was done by Mutual Housing) for early testing. Every project will have unique challenges that may be unforeseen, and this process allows issues to be identified and resolved early enough to avoid construction delays.

8. At the end of the project provide feedback to and request feedback from the project team for future improvement.

\subsection{Other Tips and Lessons Learned}

Building sealing can be a challenge in multifamily buildings, particularly when builders have no experience creating tightly sealed enclosures. The location of the air barrier should be spelled out in the drawings, and details should be provided on the work that is required and responsibilities of the different trades. Particular points where extra care should be taken in air sealing include around rim joists, at interior electrical panels, and all interior wall penetrations.

Some of the ENERGY STAR requirements require special attention. For example, meeting the Thermal Bypass Checklist Item 5.2.3: Sealing Drywall to Top Plate can be challenging and requires coordination between the drywall contractor and the insulator. For all but the top story units in multistory buildings, this seal cannot be applied from the attic; it must be applied as the drywall is installed. This requirement must be clearly specified in both the insulation and drywall contractors' scope of work and carefully coordinated.

Accessibility to mechanical equipment in interior closets should be considered during design. Because interior space is high value, builders tend to make the closets only large enough to accommodate the equipment, but this can make accessibility for installation and sealing of cabinets to plenums a challenge. The architect should consult with the mechanical consultant, and if possible, the contractor, before establishing the size of the closet.

For multifamily projects the mechanical consultant typically completes the ACCA Manual J, D, and $\mathrm{S}$ calculations and should make provisions for air balancing, return air paths, and fresh air ventilation. If this information is missing or incorrect in the plans and specifications, the added cost must be picked up by the HVAC contractor or the project developer. The engineer must understand his or her responsibility in meeting ENERGY STAR and ZERH requirements.

HVAC contractors should be made aware of the measures that are included in the Rater Checklist. For example, the ENERGY STAR Contractor Checklist does not describe a requirement for providing a return air path for bedrooms, but Section 2.8 of the Rater Checklist requires verification of adequate free area for return air, or a not-to-exceed pressure difference of $3 \mathrm{~Pa}$. For the Spring Lake project this oversight cost the developer an additional \$20,000 to install transfer grilles in all bedroom doors.

Proper design and installation of ductwork is important, even when ducts are located fully within conditioned living space. It may seem reasonable to neglect duct sealing when ducts are within conditioned space, but delivery effectiveness will still be impacted with high-leakage ducts in interior chases. Duct systems that aren't sized and balanced properly will impact comfort. Small ducts that serve closets and interior bathrooms frequently have excessive airflows, and using dampers supplied with registers is not a permanent method of balancing. Internal dampers that 
do not require attic access for making adjustments can be installed after drywall. ${ }^{15}$ Low-leakage air handlers are a good strategy in high-performance homes. When aiming for ultra-low duct leakage targets, standard air handler cabinets can contribute substantially to system leakage. Taping air handler seams takes time, and tape is often removed later when access to the inside of the cabinet is necessary.

A path for meeting ACCA Manual S equipment selection criteria for variable-speed equipment needs to be developed. The market is seeing more two-speed and variable-speed systems, and as costs fall they will become an increasingly desirable solution for high-performance homes. Some allowance for oversizing should be made if ducting is properly sized for the maximum airflow.

Information overload, particularly on projects in which team members are not experienced with ENERGY STAR and other high-performance construction standards, is a legitimate concern and can impact morale. There is no easy solution for this, but as design and construction teams become more familiar with requirements and energy-efficiency measures are increasingly adopted by codes, systems will likely be developed to efficiently handle and process information.

\footnotetext{
${ }^{15}$ For example, http://www.iaddampers.com/.
} 


\section{References}

Dakin, W., Springer, D., and Kelly, B. "Case Study: The Effectiveness of Zero Energy Home Strategies in the Marketplace.” Paper presented at the 2008 ACEEE Summer Study, Pacific Grove, CA, August 2008.

DOE. 2009. "Case Study: Pulte Homes and Communities of Del Webb - Las Vegas” Building America Best Practice Series. U.S. Department of Energy, Washington, DC (US). http://apps1.eere.energy.gov/buildings/publications/pdfs/building_america/case_study_40_pulted elwebb hotdry.pdf.

DOE. 2014. "DOE Zero Energy Ready Home California Program Requirements (Rev. 05)." U.S. Department of Energy, Washington, DC.

http://energy.gov/sites/prod/files/2013/11/f5/ch_california_requirements2013.pdf.

German, A., Bell, C., Dakin, B., and Hoeschele, M. 2014. West Village Student Housing Phase I: Apartment Monitoring and Evaluation. NREL/SR-5500-62156. National Renewable Energy Laboratory, Golden, CO (US). http://www.nrel.gov/docs/fy14osti/62156.pdf.

Griffin, A., Kaufmann, B., and Hamilton, S. (2009). Certified Home Performance: Assessing the Market Impacts of Third Party Certification on Residential Properties. Earth Advantage Institute, Portland, OR (US).

http://www.earthadvantage.org/assets/documents/AssessingMarketImpactsofThirdPartyCertificat ion-090529.pdf.

LBNL. 2011. An Analysis of the Effects of Residential Photovoltaic Energy Systems on Home Sales Prices in California. LBNL-4476E. Lawrence Berkeley National Laboratory, Berkeley, CA (US).

CEC. 2012. Reference Appendices - The Building Energy Efficiency Standards for Residential and Nonresidential Buildings. CEC-400-2012-005-CMF-REV3. California Energy Commission, Sacramento, CA (US).

PG\&E. 2014. Cottle Zero Net Energy Home Monitoring Performance Evaluation Report, 12 Months of Occupancy. Pacific Gas \& Electric Company's Emerging Technologies Program. ET13PGE101. Pacific Gas \& Electric, San Francisco, CA (US). http://www.etccca.com/sites/default/files/reports/et13pge1011 zne cottlehouse.pdf.

PNNL. 2014. “One Sky Homes: Cottle Zero Net Energy Home.” Pacific Northwest National Laboratory, Richland, WA (US).

http://energy.gov/sites/prod/files/2014/09/f18/DOE_ZEH_OneSky 9-20-14.pdf. 


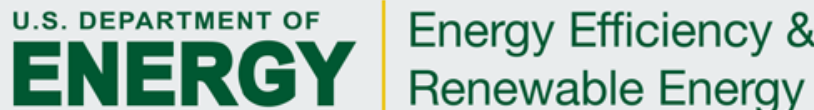

